
\title{
$\begin{array}{ll}\text { Research Square } & \begin{array}{l}\text { Preprints are preliminary reports that have not undergone peer review. } \\ \text { They should not be considered conclusive, used to inform clinical practice, } \\ \text { or referenced by the media as validated information. }\end{array}\end{array}$
}

\section{A Phylogenetic Assessment of Endocalyx (Cainiaceae, Xylariales) With E. Grossus Comb. et Stat. Nov.}

\author{
Andrew N Miller \\ University of Illinois at Urbana-Champaign \\ Akira Hashimoto \\ RIKEN Bioresource Research Center \\ Toshiya lida \\ RIKEN Bioresources Research Center \\ Moriya Ohkuma \\ RIKEN Bioresource Research Center \\ Gen Okada \\ RIKEN Bioresource Research Center
}

Gregorio Delgado ( $\square$ gregorio.delgado@eurofinset.com )

Eurofins EMLab P\&K Houston https://orcid.org/0000-0002-3274-7251

\section{Research Article}

Keywords: Anamorph (asexual/mitotic morph)^*, Palm fungi, Taxonomy, Xylariomycetidae

Posted Date: July 20th, 2021

DOI: https://doi.org/10.21203/rs.3.rs-694550/v1

License: (c) (1) This work is licensed under a Creative Commons Attribution 4.0 International License. Read Full License

Version of Record: A version of this preprint was published at Mycological Progress on January 1st, 2022. See the published version at https://doi.org/10.1007/s11557-021-01759-9. 


\section{Abstract}

The phylogenetic affinities of four representative Endocalyx taxa, including three species and two varieties, are studied based on materials collected on different palm hosts in Japan and the states of Hawaii and Texas, USA. They include specimens and their isolates belonging to E. cinctus, E. indumentum, E. melanoxanthus var. grossus and E. melanoxanthus var. melanoxanthus. Phylogenetic analyses of nuclear ribosomal DNA sequence data (ITS-LSU nrDNA) confirmed that Endocalyx belongs to the order Xylariales (Sordariomycetes) where all species and varieties treated form a strongly supported monophyletic lineage within the family Cainiaceae. They were also phylogenetically well resolved and consistent with their morphological and ecological circumscription. Species status is proposed for E. melanoxanthus var. grossus under the name E. grossus comb. et stat. nov. on the basis of its distinct morphological, molecular, cultural and ecological characteristics. The putative placement of Endocalyx within the family Apiosporaceae (Amphisphaeriales) based on the presence of basauxic conidiophores is rejected considering that all species treated clustered within the distant Cainiaceae (Xylariales). This characteristic mode of conidiophore elongation is determined to have evolved independently within unrelated or distant ascomycetous lineages. Novel morphological and cultural features of Endocalyx taxa based on new isolates are commented. The recently described $E$. metroxyli is reduced to synonym with E. melanoxanthus.

\section{Introduction}

The anamorphic genus Endocalyx Berk. \& Broome is characterized by sporodochial or synnematous, funnel-shaped, cupulate, cylindrical to pancake-shaped conidiomata arising from an annulus and containing a mass of conidia that is enclosed by yellow or brown sterile peridial hyphae (Petch 1908; Hughes 1953a; Morris 1963; Ellis 1971; Okada and Tubaki 1984; Seifert et al. 2011). Conidiophores are basauxic, hyaline to subhyaline, thread-like and branched, bearing monoblastic or polyblastic, integrated, terminal and intercalary filamentous conidiogenous cells. They produce dry, unicellular, lenticular, elliptical, almost round in one plane, but sometimes slightly angular, dark brown, blackish brown or almost black conidia, with smooth or minutely to moderately echinulate surface, rarely with hair-like projections, and often with a hyaline slit so-called germ slit. Some Endocalyx species such as E. melanoxanthus (Berk. \& Broome) Petch var. melanoxanthus and E. cinctus Petch are pantropical in distribution and saprobic on dead plant materials. They are usually found colonizing palm tree debris apparently showing a strong specificity for these hosts while others also grow on dead vines, lilies or twigs of woody trees (Hughes 1953a, 1978; Okada and Tubaki 1984).

The type species, E. thwaitesii Berk. \& Broome [= E. psilostoma Berk. \& Broome (Berkeley and Broome 1877)], first found by Petch (1908) and later confirmed by Hughes (1953a), was described according to Petch (1908) on dead leaves of Oncosperma sp. (Arecaceae) from Sri Lanka (formerly Ceylon). Hughes (1953a), however, expressed doubts whether the scanty collection deposited in IMI was a palm, originally referred to as 'dead sticks' in the protologue where no generic type was designated. Petch (1908) lectotypified the genus with $E$. thwaitesii and amended the original description based on a duplicate of the original specimen. He also described E. cinctus and transferred Melanconium melanoxanthum Berk. \& Broome to Endocalyx, collected as well in Sri Lanka on petioles of another palm tree Caryota urens L. (Berkeley and Broome 1875). Subsequently, four more species and a variety of E. melanoxanthus have been described, i.e., E. indicus J.N. Kapoor \& Munjal on dead twigs of a woody dicotyledonous plant in India (Kapoor and Munjal 1966); E. indumentum G. Okada \& Tubaki and E. melanoxanthus var. grossus G. Okada \& Tubaki on petioles of Livistona chinensis var. boninensis Becc. and Trachycarpus fortunei (Hook.) H.Wendl. (Arecaceae), respectively, in Japan (Okada and Tubaki 1984); E. collantesis J. Mena \& Mercado on dead branches of Smilax sp. (Smilacaceae) in Cuba (Mena and Mercado 1984) and E. amarkantakensis U.S. Patel, A.K. Pandey \& R.C. Rajak on dead twigs of Shorea robusta C.F.Gaertn. (Dipterocarpaceae) in India (Patel et al. 2002). Vitoria et al. (2011) accepted these seven species and two varieties although Seifert et al. (2011) recognized only five species and considered E. collantesis a synonym of E. cinctus [see also Index Fungorum (http://www.indexfungorum.org) and MycoBank (https://www.mycobank.org/)]. In a comprehensive study of the genus based on several Japanese specimens collected on palm trees, Okada and Tubaki (1984) described and isolated in pure culture $E$. melanoxanthus var. melanoxanthus, E. melanoxanthus var. grossus, E. cinctus and E. indumentum. They also conducted detailed morphological investigations on conidiogenesis and conidiomata of these and a representative collection of $E$. thwaitesii from Ghana (Hughes 1953a) using light and scanning electron microscopies. These detailed morphological studies on

Endocalyx species and other conidioma-producing fungi were later expanded to assess the taxonomic implications of conidiomatal anatomy in synnematous hyphomycetes (Okada and Tubaki 1987; Seifert and Okada 1990). Recently, a further eighth species 
named E. metroxyli Konta \& K.D. Hyde was described from a dead petiole of the palm tree Metroxylon sagu Rottb. in Thailand using both morphological and molecular data (Konta et al. 2021).

The phylogenetic position of Endocalyx has been the subject of speculation since the introduction of the genus. Berkeley and Broome (1877) first considered it was closely allied to Alwisia Berk. \& Broome, a genus of myxomycetes (Mycetozoa, Amoebozoa). Later, Petch (1908) rejected this hypothesis and compared Endocalyx with Graphiola phoenicis (Moug. ex Fr.) Poit. to conclude that in all essential details they were dissimilar although he did not exclude some reminiscences with other Graphiola species. Corte (1963), however, included the genus within the family Graphiolaceae, at that time belonging in the now defunct "Fungi Imperfecti", and provided a key for the three species known at the time. This genus and particularly G. phoenicis are now well resolved within the Exobasidiales (Ustilaginomycotina, Basidiomycota) based on morphological, ultrastructural, life cycle and molecular data (Begerow et al. 2006). Hyde et al. (1998), on the other hand, suggested that Endocalyx as well as other anamorphic genera may belong to the family Apiosporaceae (Amphisphaeriales) due to the presence of basauxic conidiophores. The criterion for this tentative placement probably followed Hughes (1953b) who included Arthrinium Kunze, Endocalyx, Dictyoarthrinium S. Hughes, Spegazzinia Sacc., Graphiola and Papularia Fr. in his section VIII. This group was characterized by basauxic conidiophores that elongate by a basal growing point and arise from a swollen "conidiophore mother-cell" with the oldest conidia towards the apex and the youngest towards the base of the conidiophores. Minter (1985) reviewed conidial development in Arthrinium and morphologically related genera such as Endocalyx and Nigrospora Zimm. to conclude that they were indeed closely related. He predicted that any teleomorphs found in fungi belonging to the "Arthrinium group" will occur in and around the genus Apiospora Sacc. Similarly, Arx (1985) considered that genera with basauxic conidiogenesis and pigmented, often oblate or bilaterally flattened conidia growing mainly on litter of monocotyledons, especially grasses and palms, represented a phylogenetic entity. Kendrick and Murase (1994) assembled informal groups of anamorphs with shared features and speculated whether the relatively rare basauxic development in conjunction with other unusual features such as thick, darkly pigmented septa of the conidiogenous axis arising from a phialide-like mother cell and conidia with germ slits represented a monophyletic group. Nevertheless, they considered that their putative groupings may ultimately have to be confirmed or rejected by molecular data. The hypothetical placement of Endocalyx in Apiosporaceae and its close relationship with Arthrinium has been widely accepted (Taylor and Hyde 2003; Senanayake et al. 2015; Wijayawardene et al. 2017, 2018, 2021; Hyde et al. 2020). However, Konta et al. (2021) recently reassigned Endocalyx to the family Cainiaceae (Xylariales) employing molecular data for the first time based on a limited taxon sampling including only sequences of E. cinctus available in GenBank (http://www.ncbi.nlm.nih.gov/genbank/) and those of a novel species named E. metroxyli described from Thailand.

During recent surveys of saprobic microfungi carried out by one of the authors (G.D.) in subtropical Texas, USA, specimens of $E$. melanoxanthus var. melanoxanthus were collected on palm tree debris and isolated in pure culture. In order to confirm the phylogenetic placement and taxonomic status of Endocalyx on the basis of a more extensive taxon sampling, DNA sequence data was generated from these and the morphologically and culturally well-characterized voucher specimens and strains described by Okada and Tubaki (1984) in their seminal paper about the genus including two ex-holotype strains. Other unpublished specimens and cultures of Endocalyx species obtained by another author (G.O.) mainly in Japan (Sato et al. 1991) were also used in this study for a more comprehensive assessment. Results are presented here and a new combination at species level is introduced based on morphological and molecular evidence.

\section{Materials And Methods}

\section{Morphological and cultural studies of specimens and isolates}

Two fresh specimens of E. melanoxanthus var. melanoxanthus were collected on dead inflorescences of the palm tree Sabal minor (Jacq.) Pers. (Arecaceae), the dwarf palmetto, during fieldwork carried out by G.D. in southeastern Texas in 2020. Conidiomata were recognized in the field using a hand lens and pieces of substrate showing colonies were brought to the lab for processing. They were briefly washed off under tap water and incubated in a moist chamber at room temperature $\left(23-25^{\circ} \mathrm{C}\right)$ for three weeks followed by periodical examinations under the stereoscope to observe the development of conidiomata and to take images. Single spore isolations from conidiomata were made following Choi et al. (1999). Germinated conidia were transferred aseptically to $2 \%$ Malt Extract Agar with $0.01 \%$ chloramphenicol (MEA: Hardy Diagnostics, Santa Maria, California, USA) and incubated at $25^{\circ} \mathrm{C}$. Colony features were recorded after two weeks under similar conditions. Fungal structures were mounted in lacto-cotton blue for 
examination under BX45 microscope (Olympus, Tokyo, Japan). Minimum, maximum, 5th and 95th percentile values were calculated based on 50 measurements of each structure at 1000x magnification and outliers are given in parenthesis. Voucher specimens are deposited in ILLS (Illinois Natural History Survey Fungarium, Champaign, llinois, USA) and living strains in CBS (Westerdijk Fungal Biodiversity Institute, Utrecht, Netherland). Images of conidiomata in Texas specimens were obtained with an Olympus E-520 digital camera attached to an Olympus SZ61 stereomicroscope. They were stacked using the CombineZP focus stacking software v.1.0 (https://combinezp.software.informer.com/). The abbreviation FSCl is used to further refer to them in figure legends.

A set of twenty-two Endocalyx strains currently deposited at the Japan Collection of Microorganisms (JCM), RIKEN BioResource Research Center, Tsukuba, Japan, and two others hosted at the Biological Resource Center (NBRC), National Institute of Technology and Evaluation (NITE), Kisarazu, Japan, were also studied (Table 1). Sixteen of them were originally collected and isolated by Okada and Tubaki (1984) on decaying petioles and peduncules of palm hosts at different locations of Japan between the years 1981 and 1983. They were morphologically characterized in detail on natural substrates and eight different culture media, and originally deposited at the Institute of Biological Sciences, University of Tsukuba, Tsukuba (TKB) as TKBC and the Institute for Fermentation (IFO), Osaka. They are currently preserved at NBRC with identical IFO accession numbers. Most duplicate strains except NBRC 31306 and 31299 are available at JCM and some at CBS. The corresponding voucher specimens were originally deposited at TKB as TKBF, but they were incorporated in 2012 into the Herbarium of the National Museum of Nature and Science, Tsukuba (TNS) with a TNS-F accession number. They are available for search at the NMNS Collection Database of Specimens and Materials (http://db.kahaku.go.jp/webmuseum_en/). Some duplicates were also deposited at IMI and CBS-H.

Eight specimens and strains not originally studied by Okada and Tubaki (1984) but collected and isolated later by G.O. following identical procedures were included. Potato Dextrose Agar (PDA; Nissui Pharmaceutical Co. Ltd., Tokyo, Japan) was mainly used for isolating and culturing these strains. To attempt sporulation, some Japanese isolates were incubated on autoclaved wet petioles of suitable palm hosts placed on thick water agar plates in an unsealed glass Petri dish (or that with high waist) at room temperature under prolonged incubation for several months or over a year. To obtain focus stacking composite images of conidiomata in Japanese specimens or isolates, a Z16 APO macroscope (Leica Microsystems, Wetzlar, Germany) with installed CombineZP software v.1.0 was used. An Orthoplan microscope with a phase contrast device (Leitz, Wetzlar, Germany) and a Biophot microscope with a differential interference contrast device (Nikon, Tokyo, Japan) were also employed (PC \& DIC; abbr. used in figure legends). Photos were recorded by Leica MC190 HD and Nikon DS-5M/DS-Fi1 digital cameras, and some photos were prepared as composite images (Cl; abbr. used in figure legends). Voucher specimens collected by G.O. are deposited mainly in TNS and partly in ILLS. Strains are available for search at the JCM On-Line Catalogue of Strains (https://jcm.brc.riken.jp/en/catalogue_e). A total of twenty-six Endocalyx strains were included in this study and their specific information is available in Table 1. Fungal names follow MycoBank and the International Plant Names Index (https://www.ipni.org) for host plant names. Herbaria and culture collection acronyms are cited according to Index Herbariorum (http://sweetgum.nybg.org/science/ih/) and Culture Collections Information Worldwide (CCINFO; http://www.wfcc.info/ccinfo/) of the WFCC-MIRCEN World Data Center for Microorganisms (WDCM), respectively.

\section{DNA extraction, PCR amplification and sequencing}

Genomic DNA was extracted from fungal mycelia grown on MEA using a modified NaOH extraction method (Osmundson et al. 2013), which consisted of adding $200 \mu \mathrm{L} 0.5 \mathrm{M} \mathrm{NaOH}$ to $\sim 75 \mathrm{mg}$ of tissue, grinding with a micropestle, centrifugation at 14,000 RPM for 2 minutes, and adding $5 \mu \mathrm{L}$ of the resulting supernatant to $495 \mu \mathrm{L} 100 \mathrm{mM}$ Tris-HCl buffered with $\mathrm{NaOH}$ to $\mathrm{pH}$ 8.5-8.9 (Tris-HCl-DNA extraction solution). The complete nrDNA internal transcribed spacer (ITS) region and the first 1,100 bp of the 5' end of large subunit nrDNA (LSU nrDNA) were amplified as two overlapping regions. PCR amplification using a GoTaq ${ }^{\circledR}$ Green Master mix (Promega, Madison, Wisconsin, USA) consisted of the following: $12.5 \mu \mathrm{L}$ GoTaq $^{\circledR}$ Green Master mix, $2.5 \mu \mathrm{L}$ BSA, $2.5 \mu \mathrm{L} 50 \%$ DMSO, $2 \mu \mathrm{L}$ of each $10 \mu \mathrm{M}$ primer ITS1F/LR3 or LROR/LR6, and $3 \mu \mathrm{L}$ DNA. PCR amplification was completed on a Bio-Rad PTC 200 thermal cycler under the following parameters: Initial denaturation at $94^{\circ} \mathrm{C}$ for 2 minutes, followed by 40 cycles of $94{ }^{\circ} \mathrm{C}$ for 30 seconds, $47^{\circ} \mathrm{C}$ for 30 seconds, $72{ }^{\circ} \mathrm{C}$ for 1 minute with a final extension step of $72{ }^{\circ} \mathrm{C}$ for 10 minutes. Gel electrophoresis $(1 \%$ TBE agarose gel stained with ethidium bromide) was used to verify the presence of a PCR product. PCR products were purified using a Wizard ${ }^{\circledR}$ SV Gel and PCR Clean-Up System (Promega), and template DNA was used in $10 \mu \mathrm{L}$ sequencing reactions with BigDye ${ }^{\circledR}$ Terminator v3.1 (Applied Biosystems, Foster City, California, USA) using a combination of the following primers: ITS1F, ITS4, LROR,

Page $4 / 26$ 
LR3, LR3R and LR6 (Vilgalys and Hester 1990; White et al. 1990; Gardes and Bruns 1993; Rehner and Samuels 1995). Sequences were generated on an Applied Biosystems 3730XL high throughput capillary sequencer at the W.M. Keck Center at the University of Illinois Urbana-Champaign. In the case of the JCM strains, they were first grown on PDA and genomic DNA extraction, PCR amplification and sequencing were performed following the previously reported method (Hashimoto et al. 2021). Consensus ITSLSU sequences were assembled with Sequencher 5.4 (Gene Codes Corp., Ann Arbor, Michigan, USA) and deposited in GenBank.

\section{Taxon sampling and datasets}

The novel Endocalyx sequences obtained from the Japanese, Hawaiian and Texan strains were subjected to megablast searches in GenBank database to first explore their identity and phylogenetic position. The closest hits from blast searches were representatives of Xylariales, particularly members of the families Cainiaceae and Xylariaceae, which were selected and downloaded to assemble the combined ITS-LSU dataset. Exception was the only available LSU sequence of Seynesia erumpens (Berk. \& M.A. Curtis) Petr. (AF279410) which produced incongruent results during subsequent analyses and was removed from the final dataset. Additionally, ITS-LSU sequences of E. cinctus JCM 7946 available in GenBank and those belonging to the recently described E. metroxyli (Konta et al. 2021) were also added to the datasets. An additional ITS sequence from a specimen identified as Endocalyx sp., collected in the Ogasawara (Bonin) Islands (Tanaka et al. 2017) and currently deposited in the NARO Genebank, Microorganism Section, Ministry of Agriculture, Forestry and Fisheries, Tsukuba, Japan (MAFF), was retrieved from NARO Genebank database (https://www.gene.affrc.go.jp/databases_en.php) and added to the ITS dataset. Additional sequences from recent phylogenetic studies of Xylariales (Jaklitsch et al. 2014, 2016; Senanayake et al. 2015; Hyde et al. 2020) were also included (Table 2). To confirm the hypothesis whether Endocalyx species are putative members of Apiosporaceae some sequences of representative taxa of Arthrinium (=Apiospora) and Nigrospora Zimm. obtained from Crous and Groenewald (2013) and Wang et al. (2017) were also incorporated in the datasets. The strains Achaetomium macrosporum CBS 532.94, Chaetomium elatum CBS 374.66 and Sordaria fimicola CBS 723.96 (Sordariales) were selected as outgroups.

\section{Phylogenetic analyses}

Sequences were aligned with MAFFT v. 7.475 (Katoh and Standley 2013) on the online server which automatically selected the FFTNS-i iterative refinement strategy (Katoh et al. 2002) for both the ITS and LSU datasets. Alignments were edited and concatenated using MEGA6 (Tamura et al. 2013) and Maximum Likelihood (ML) and Bayesian inference (BI) approaches were used to infer phylogenetic relationships in RAxML v.8.2.12 (Stamatakis 2014) and MrBayes 3.2.7a (Ronquist and Huelsenbeck 2003, Ronquist et al. 2012), respectively, on the CIPRES Science Gateway server (Miller et al. 2010). ML analysis was run under the GTR+CAT model using the rapid bootstrapping algorithm and 1,000 bootstrap iterations to estimate branch support with bootstrap support (BS) values $\geq 70 \%$ considered significant (Hillis and Bull 1993). The best fit-substitution model for the combined ITS-LSU dataset as determined in MEGA using the corrected Akaike Information Criterion value was the GTR+G+I. Bayesian inference analysis consisted of two independent runs of 10 million generations with four (one cold and three heated) Markov Chain Monte Carlo chains each starting from different random trees with default prior values and trees sampled every 100 th generation. The first $25 \%$ of trees were discarded as burn-in prior to convergence and the remaining trees were used to compute a $50 \%$ majority rule consensus tree and estimate posterior probabilities (BPP) for each node. Analyses were set to stop when the standard deviation of split frequencies decreased below 0.01 and convergence of runs was further diagnosed in Tracer v1.6.0 (Rambaut et al. 2014). Clades were considered statistically significant when BPP $\geq 0.95$ (Alfaro et al. 2003). Trees were edited in MEGA and further refined using Inkscape (https://inkscape.org). All alignments and resulting trees are deposited in TreeBASE (https://treebase.org/, study number S19717).

\section{Results}

\section{Molecular analyses}

Pairwise comparisons of the ITS and LSU sequences belonging to the Japanese, Hawaiian and Texan specimens of $E$. melanoxanthus var. melanoxanthus showed they are nearly identical except for one C-T transition at position 421 of the ITS alignment in strains JCM 5156, JCM 5159, JCM 5161, JCM 7948 and NBRC 31299, and one G-A transition at position 396 of the LSU alignment in strain JCM 5159. Similarly, strains MFLUCC 15-0723A, B and C belonging to E. metroxyli collected in Thailand differed only by one T-C transition at position 49 of the ITS alignment whereas their LSU sequences were identical to those of the 
studied E. melanoxanthus var. melanoxanthus strains. In contrast, the strain Endocalyx sp. MAFF 244025 showed a total of $15 \mathrm{bp}$ and one gap differences compared with the remaining ITS sequences. In the case of E. melanoxanthus var. grossus, all ITS sequences were identical except for the LSU of JCM 5167 which contained a C-T transition at position 430 of the alignment. The ITS and LSU sequences of E. cinctus strains each showed three nucleotide differences between them whereas they were identical between E. indumentum strains.

The combined ITS-LSU alignment consisted of 102 sequences and 1,683 positions including the outgroups, 897 from the ITS alignment and 786 from the LSU. The single best RAxML tree $(\mathrm{In}=-17725.715920)$ resulted from the ML analysis is shown in Fig. 1 with E. melanoxanthus var. melanoxanthus, E. melanoxanthus var. grossus and E. metroxyli as E. melanoxanthus, "E. grossus" and $E$. melanoxanthus, respectively. The $M L$ tree topology was similar in topology to the $50 \%$ majority rule consensus tree of the 6,688 sampled trees from the Bayesian analysis. Effective sample size values of all relevant parameters were $>200$ as verified in Tracer, indicating adequate sampling of the posterior distribution (Drummond et al. 2006; Drummond and Rambaut 2009). The twenty-six Endocalyx strains formed a strongly supported monophyletic group (97\% BS, 1.0 BPP) within the family Cainiaceae. Each species and variety were well resolved, and they split in two subclades: one including E. melanoxanthus var. melanoxanthus, E. indumentum and E. cinctus and the other containing only E. melanoxanthus var. grossus. The Japanese, Hawaiian and Texan strains of E. melanoxanthus var. melanoxanthus formed a strongly supported monophyletic group (100\% BS, 1.0 BPP). The three strains belonging to E. metroxyli from Thailand (MFLUCC 15-0723A, B and C, obtained from the same single specimen) and that one of Endocalyx sp. MAFF 244025 from Japan also clustered within this clade indicating they are conspecific with $E$. melanoxanthus var. melanoxanthus. They grouped sister to the two available strains of $E$. indumentum including an ex-holotype (JCM 5171) without significant BS support but showing significant BPP $=0.98$. Strains of $E$. indumentum, $E$. cinctus and $E$. melanoxanthus var. grossus including an ex-holotype (JCM 5164) each formed highly supported clades ( $99 \%$ or $100 \%$ BS, 1.0 BPP). The four taxa of Endocalyx shown in Fig. 1 were clearly recognized at species level and not at variety level. Therefore, $E$. melanoxanthus var. melanoxanthus and E. melanoxanthus var. grossus should be treated as E. melanoxanthus and "E. grossus" and a new taxonomic treatment is proposed below for the latter. The Endocalyx lineage was sister to a moderately supported monophyletic group including Cainia graminis (Niessl) Arx \& E. Müll., the type species of Cainia Arx \& E. Müll., and other members of Cainiaceae (Xylariales) belonging to three different genera. The family was recovered as a highly supported monophyletic clade (99\% BS, 1.0 BPP). Arthrinium and Nigrospora species grouped together in a highly supported clade (98\% BS, 1.0 BPP) representing the family Apiosporaceae in the distant order Amphisphaeriales (Xylariales after MycoBank and NCBI Taxonomy).

\section{Taxonomy}

Endocalyx cinctus Petch, Ann. Bot. (London) 22: 394 (1908). (Figs. 3F, G, 4A)

Materials examined: Japan, Tokyo, Ogasawara Islands, Anijima Island, on peduncle of dead inflorescence of Livistona chinensis var. boninensis, 18 Mar. 1990, leg. \& det. G. Okada [TNS-F-91424 = G. Okada Ogasawara-191; strain JCM 7946; TNS-F-91425 (dried culture of JCM 7946 incubated on autoclaved petiole of L. chinensis var. subglobosa (Hassk.) Becc.)]; idem [ILLS $121502=$ G. Okada Ogasawara-192 (together with E. melanoxanthus)].

Notes: Morphologically, the specimen studied (TNS-F-91424) agrees well with the description provided by Okada and Tubaki (1984). In culture, strain JCM 7946 produced conidiomata (Fig. 3G) and conidia (Fig. 4A) on autoclaved petioles of L. chinensis var. subglobosa after three month-incubation period that were almost the same as those on palm hosts (Fig. 3F). The conidial surface was slightly rough especially in young conidia (Fig. 4A). Endocalyx cinctus is the best species for inducing conidiomata and conidia on autoclaved petiole of palms (Okada and Tubaki 1984; this paper). After further prolonged incubation on autoclaved petiole of L. chinensis var. subglobosa, irregularly shaped conidiomata including subspherical ones were produced (TNS-F-91425).

Endocalyx grossus (G. Okada \& Tubaki) G. Delgado \& G. Okada, comb. et stat. nov. (Figs. 3B-D, 4G-I, 5A-E)

MycoBank MB817907

Basionym: Endocalyx melanoxanthus var. grossus G. Okada \& Tubaki, Mycologia 76: 303 (1984).

Typification: Japan, Ibaraki, Tsukuba, Higashioka, 36 $05^{\prime} 46.6^{\prime \prime} \mathrm{N} 140^{\circ} 07^{\prime} 34.2^{\prime \prime E}$, on dead petiole of Trachycarpus fortunei, 6 Aug. 1982, leg. G. Okada, TNS-F-18281 (TKBF 5027, holotype); ex-holotype strain NBRC 31308 = JCM $5164=$ CBS $105.86=$ G. Okada 
OFC 1116).

Materials examined: Japan, Saitama, Ogawa-machi, Otsuka, 36²03'28.4" N, $139^{\circ} 15^{\prime} 03.3^{\prime \prime} \mathrm{E}$, on dead petiole of T. fortunei, 2 Sep. 2017, leg. \& det. G. Okada (TNS-F-91426 = G. Okada 1763; strain JCM 32411); idem (ILLS 121505 = G. Okada 1764); idem, Koshigoe, near Tatekawa Dam, 3601'13.8" N, 139 $12^{\prime} 40.0^{\prime \prime}$ E, on dead petiole of T. fortunei, 23 Jul. 2018, leg. \& det. G. Okada [TNSF-91427 = G. Okada 1766; strain JCM 32997; TNS-F-91428 (dried culture of JCM 32997 incubated on autoclaved petiole of $T$. fortunei)]; idem (ILLS 121504 = G. Okada 1767); Ibaraki, Bando, Oguchi, 36²02'26.5" N, 139 $56^{\prime} 09.6^{\prime \prime} \mathrm{E}$, on dead petiole of T. fortunei, 23 Jul. 2018, leg. \& det. G. Okada [TNS-F-91429 = G. Okada 1769; strain JCM 32998; TNS-F-91430 (dried culture of JCM 32998 incubated on autoclaved petiole of T. fortunei)]; idem (ILLS $121506=$ G. Okada 1770); Saitama, Chichibu, Hinoda-machi, Business office of the University of Tokyo Chichibu Forest, $35^{\circ} 59^{\prime} 19.1^{\prime \prime} \mathrm{N}, 139^{\circ} 04^{\prime} 48.3^{\prime \prime} \mathrm{E}$, on dead petiole of T. fortunei, 13 Sep. 2018, leg. \& det. G. Okada (TNS-F-91431 = G. Okada 1772; strain JCM 33339).

Notes: Okada and Tubaki (1984) morphologically distinguished E. melanoxanthus var. grossus from E. melanoxanthus var. melanoxanthus based on the brown to yellowish brown colour of the peridial hyphae enclosing the conidial mass, which is vivid yellow to greenish yellow in the latter, and the verrucose conidial wall ornamentation. This is relatively smooth to tuberculate under light microscopy but scanning electron microscopy (SEM) clearly revealed a thin outer layer that cracks and forms coarse-relief islets evenly distributed over the conidial surface. Moreover, the colour of conidial mass in E. melanoxanthus var. melanoxanthus is somewhat glistening blackish than the variety grossus. Differences in conidiomata were less evident, except the colour of the peridial hyphae, but the variety grossus forms mostly cupulate, rarely cylindrical and usually smaller conidiomata, $0.2-0.3 \mathrm{~mm}$ and up to $3 \mathrm{~mm}$ high, while those of the variety melanoxanthus are $0.5-1 \mathrm{~mm}$ and can reach up to $7 \mathrm{~mm}$ high. Ecologically, this taxon is apparently restricted and known so far only from $T$. fortunei, the windmill palm, one of the best-known cold-hardiest species of Arecaceae. Conidia of variety grossus developed readily in culture compared to the variety melanoxanthus (Okada and Tubaki 1984). Clavate chlamydospore-like conidia were also formed in culture, but much obvious in the variety melanoxanthus, and growth was observed at $5^{\circ} \mathrm{C}$ after three months whereas other Endocalyx taxa did not grow under these conditions. In addition to these differences, the eleven strains belonging to the variety grossus, including an ex-holotype strain, grouped together with high support in our concatenated analyses of ITS and LSU sequence data distant from those of the variety melanoxanthus. Considering all the morphological, ecological, cultural and molecular evidence based on multiple specimens and cultures (Seifert and Rossman 2010), the variety grossus is elevated here to species rank distinct from E. melanoxanthus and the remaining Endocalyx species.

In culture, strain JCM 32998 produced conidial columns (Fig. 4G arrows) on autoclaved petiole of $T$. fortunei. They consisted of almost rough conidia (Fig. 4I) and emerged from an annulus-like structure (Fig. $4 \mathrm{G}$ white arrowheads) associated with hemispherical to subspherical conidiomata (Fig. 4G black arrowheads). In the case of strain JCM 5164 (ex-holotype) and JCM 32997, many smaller conidiomata were produced on the autoclaved substrate under prolonged incubation. Moreover, it was observed that under the same conditions JCM 32997 developed a few conidial columns with brown peridial hyphae from an annulus-like structure (Fig. 4H). This conidiomatal structure is basically the same as that on the palm host. On the other hand, strain JCM 5166 abundantly developed similar subspherical conidiomata of various sizes on PDA under prolonged incubation and without any autoclaved substrate (Fig. 5A). Dark brown conidial mass appeared from broken conidiomata (Fig. 5B, C arrowheads), and conidial columns (Fig. 5D, E arrows) were produced from the lower part of broken conidiomata (Fig. 5D, E arrowheads), which were very similar to the annulus-like structure formed on autoclaved petiole of T. fortunei (Fig. 4G white arrowheads).

Endocalyx indumentum G. Okada \& Tubaki, Mycologia 76: 305 (1984). (Figs. 3E, 4B-F, 5F)

Materials examined: Japan, Tokyo, Ogasawara Islands, Chichijima Island, Suzaki, on dead petiole of Phoenix canariensis H.Wildpret, 12 Mar. 1990, leg. \& det. G. Okada [ILLS 121501 = G. Okada Ogasawara-80 (together with E. melanoxanthus, no isolate)]; idem, Anijima Island, on peduncle of dead inflorescence of Livistona chinensis var. boninensis, 18 Mar. 1990, leg. \& det. G. Okada (ILLS 121503 = G. Okada Ogasawara-194); idem [TNS-F-91432 = G. Okada Ogasawara-200; strain JCM 8042; TNS-F-91433 (dried culture of JCM 8042 incubated on autoclaved petiole of L. chinensis var. subglobosa)].

Notes: Morphological details of the specimen studied (TNS-F-91432) agree well with the description of Okada and Tubaki (1984). In culture, strain JCM 8042 formed primordium-like structures of conidiomata on autoclaved petiole of L. chinensis var. subglobosa after three month-incubation period. Hemispherical to subspherical conidiomata were produced on the surface of the substrate after further prolonged incubation, and dark brownish conidial masses in columns or not emerged from inside of burst conidiomata 
(Fig. 4C, D arrow \& arrowheads; TNS-F-91433). Conidia with hair-like projections (Fig. 4E, F) were the same as those on palm hosts (Okada and Tubaki 1984, Fig. 23). The strain JCM 5171 (ex-holotype) did not produce conidiomata in the same conditions this time. On the other hand, strain JCM 8042 developed subspherical conidiomata on PDA under prolonged incubation and without any autoclaved substrate (Fig. 5F). In the broken conidiomata (Fig. 5F arrowheads), small immature conidia without filamentous ornamentation were observed as reported by Okada and Tubaki (1984, Fig. 24).

Endocalyx melanoxanthus (Berk. \& Broome) Petch, Ann. Bot. (London) 22: 390 (1908). (Figs. 2, 3A)

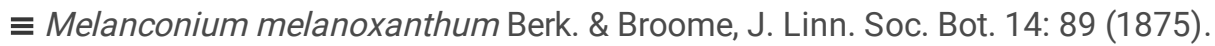

$=$ Endocalyx metroxyli Konta \& K.D. Hyde, in Konta et al., Life 11(486): 18 (2021).

Conidiomata scattered or aggregated in small to large groups and emerging from an annulus-like, black, circular pustules, at first short-cylindrical or short-cupulate becoming long cylindrical, subcylindrical, long conical or cup-shaped after incubation for several days, reaching up to $3 \mathrm{~mm}$ high in well-developed fructifications and consisting of a black, glistening mass of conidia enclosed by a yellow to greenish yellow or orange yellow, annular mass of sterile peridial hyphae which remain at the base once the conidioma expands and grows upwards surrounding the column of conidia. Conidiophores micronematous, filiform, flexuous, hyaline, septate, smooth, anastomosing, 1-2.5(-3.5) $\mu \mathrm{m}$ wide. Conidiogenous cells holoblastic, monoblastic, integrated, terminal or intercalary, cylindrical, minutely denticulate. Conidia solitary, dry, globose, subglobose or broadly ellipsoidal, slightly polygonal and flattened in front view, $(10-) 12-16 \times 9-12(-13) \mu \mathrm{m}$, ellipsoidal, lenticular or rarely oblong in lateral view, $(7-) 8-9(-10) \mu \mathrm{m}$ thick, with a paler equatorial germ slit, aseptate, brown, dark brown or blackish brown, thick-walled, smooth to finely roughened, often with a central or nearly central attachment scar.

Colonies on MEA moderately fast growing reaching $25-35 \mathrm{~mm}$ diam. after 10 days at $25^{\circ} \mathrm{C}$, cottony, white, up to $5 \mathrm{~mm}$ high at the center, flat and dull-white toward the edge, margin entire, sometimes with visible yellow bands or yellowish spots; reverse dull white, yellowish at the center. Sporulation not observed after 3 months. Chlamydospores present, abundant in gray or blackish patches immersed under the superficial mycelium, terminal or intercalary, solitary or catenate and in short chains of up to 6, globose, subglobose, ellipsoidal, long ellipsoidal, subcylindrical, long cylindrical or elongated, rarely narrowly clavate or pyriform when terminal, straight or flexuous to curved, pale brown to brown or dark brown, thick-walled, smooth, 0(-1)-septate, at times slightly constricted around the center, sometimes with a paler equatorial germ slit, 8-24(-29) $\times 5-9(-11) \mu \mathrm{m}$.

Materials examined: USA, Texas, Harris County, Spring, Meyer Park, 3000'15.9" N, 95³1'35.7" W, 33 m a.s.l., on peduncle of dead inflorescence of Sabal minor, 20 Sep. 2020, leg. \& det. G. Delgado (ILLS 121433; strain CBS 147393); idem, on spathe of dead inflorescence of S. minor, 20 Sep. 2020 (ILLS 121434; strain CBS 147394).

Other materials examined: Japan, Tokyo, Ogasawara Islands, Chichijima Island, Suzaki, on dead petiole of Livistona chinensis var. boninensis, 12 Mar. 1990, leg. \& det. G. Okada (TNS-F-91434 = G. Okada Ogasawara-61; strain JCM 7948); USA, Hawaii, Hawaii Island, Hilo, around Liliuokalani Park and Gardens, on dead petiole of Cocos nucifera L., 2 Aug. 2005, leg. \& det. G. Okada (ILLS 121495; strain JCM 13432); ILLS 121502 and ILLS 121501 (see the above sections of E. cinctus and E. indumentum for collection details).

Notes: Our specimens agree well with previous descriptions of the fungus in having distinct annular, vivid or greenish yellow fructifications surrounding a black mass of subglobose, more or less angular, dark brown to blackish brown, aseptate conidia with a paler germ slit. Conidiomata readily developed after incubation for a few days and the conidial mass together with the yellow peridial hyphae expand upward forming long cylinders up to $3 \mathrm{~mm}$ high in the longer fructifications. Okada and Tubaki (1984) also obtained morphologically similar, well-developed conidiomata in moist chamber that reached up to $7 \mathrm{~mm}$ high. The moisture conditions induced abundant sporulation that cannot be held by the outer layer of peridial hyphae and tears laterally in several places or apically, opening up and releasing spores on the substrate (Fig. 2D-F). Wall ornamentation of conidia was confirmed to be very finely roughened and more visible around the paler wall of the germ slits in agreement with Okada and Tubaki (1984), who reported a fine dust-like layer covering conidia which cracks and creates islets as seen under SEM. In culture, the Texas strains did not sporulate after three months incubation on MEA, but they produced abundant chlamydospores in the same time period (Fig. $2 \mathrm{~J}-\mathrm{L}$ ). This also agrees with Okada and Tubaki (1984) who reported solitary or catenate, terminal or intercalary, dark brown, similar 
in size and shape chlamydospores, with a paler germ slit and superficially resembling conidia. They also obtained immersed or superficial, pycnidioid conidiomata on sterilized wooden chips that produced conidia similar to those on natural substrate, but this technique to induce sporulation was not attempted this time for the Japanese, Hawaiian and Texan strains.

\section{Discussion}

This study represents a comprehensive assessment of the phylogenetic affinities of four Endocalyx taxa employing molecular data obtained from specimens and strains collected in Japan, Hawaii and continental USA. Our phylogenetic analyses using a more extensive taxon sampling than that of Konta et al. (2021) confirmed that Endocalyx belongs to the order Xylariales (Sordariomycetes) and its familial position is resolved within the Cainiaceae. All species treated formed a distinct monophyletic lineage and they grouped with representative members of the family including Cainia graminis, the type species of Cainia, type genus of the family. Molecular data along with distinct morphological, cultural and ecological features support well the recognition of $E$. grossus, originally described as a variety of $E$. melanoxanthus, as a separate species. The remaining three taxa, E. cinctus, $E$. indumentum and E. melanoxanthus, were also phylogenetically well resolved (Fig. 1) and all treated Endocalyx species were consistent with their morphological circumscription mainly based on conidiomata morphology, presence or absence of a carbonaceous hyphal cylinder at the base of conidiomata, colour of the peridial hyphae and conidial mass, conidial wall ornamentation, and palm host preferences (Okada and Tubaki 1984).

On the hosts and in culture, the morphological and cultural features of conidiomata and conidia of Endocalyx species newly collected in Japan and USA agree quite well with Okada and Tubaki (1984) and other previous papers (Petch 1908; Hughes 1953a). In addition to a new taxonomy for E. melanoxanthus var. grossus and the description of E. melanoxanthus based on the Texas specimens, novel observations and comments on other Endocalyx taxa are also added. In culture, Endocalyx grossus, E. indumentum, E. cinctus, and E. melanoxanthus produce subspherical pycnidioid conidiomata on autoclaved palm/wooden chips and agar media such as PDA and others (Okada and Tubaki 1984; this paper; Fig. 4C, D, G, Fig. 5). These conidiomata lack ostioles resembling "asexual cleistothecium-like conidiomata", and conidia are released by cracking of the outer walls (Fig. 5C, F). In the case of E. cinctus, conidiomata are unique in morphology among Endocalyx species and consist of synnemata with a bilayered cortex on natural substrate (Fig. 3F) or with a spherically swollen carbonaceous base in culture (Okada and Tubaki 1984, 1987; Seifert and Okada 1990). These morphologically unique features of E. cinctus might become the subject of a future analysis research project using its whole genome available in GenBank (BCKC00000000).

Although Endocalyx is revealed as a phylogenetically, morphologically and ecologically well-defined genus based on these several specimens and isolates, E. twaithesii, the generic type, is not sequenced yet. Therefore, the generic position revealed by Konta et al. (2021) and this study, although including ex-holotype strains of species such as E. grossus and E. indumentum, still requires confirmation through sequences from E. twaithesii. An online search on the IMI database

(http://www.herbimi.info/herbimi/home.htm) shows that two specimens of E. twaithesii, type specimen from the original collection Thwaites 1408 in Sri Lanka (IMI 48588a) and another authentic specimen collected by S. Hughes in Ghana (formerly Gold Coast) [IMI 43614c, on twigs of Cissus oreophila Gilg \& M. Brandt (Vitaceae)], are currently deposited in IMI. Future recollection of fresh authentic materials of $E$. twaithesii at the type locality (Sri Lanka) is needed to further evaluate the phylogenetic status of the genus.

The recently described $E$. metroxyli collected in Thailand on a dead petiole of $M$. sagu (Konta et al. 2021), clustered within the $E$. melanoxanthus clade (Fig. 1) and therefore it was reduced to its synonym (see the taxonomic part of E. melanoxanthus). Morphologically, the authors recognized that $E$. metroxyli was very close to E. melanoxanthus in having similar black annulus-like pustules, the fertile centre enclosed by yellow peridial hyphae, and conidia nearly identical in size. The only distinctive features to separate them were the lack of cupulate or cylindrical conidiomata and the absence of thread-like conidiophores in E. metroxyli. In our experience, however, after examining several specimens of $E$. melanoxanthus on natural substrate before and after incubation in moist chamber, conidiomata of the Thailand specimen MFLU 15-1454 (Konta et al. 2021, Figs. 3C-E) seem to be poorly developed and sporulated probably due to its surrounding environmental conditions. This is confirmed by the specimen collection date that took place during the tropics drier season (December) and no mention of subsequent incubation procedure was made. The expansion and development of fully cupulate, cylindrical or funnel-shaped conidiomata in E. melanoxanthus, E. grossus and E. indumentum seem to be enhanced under conditions of high moisture (Okada and Tubaki 1984; this paper). Example is the visible 
differences in conidiomata development seen in specimen E. melanoxanthus ILLS 121433 on the host before and after incubation in moist chamber [Fig. 2C (before), D-F (after)]. Moreover, thread-like conidiophores are usually difficult to find and especially in a poorly sporulated specimen but they can be detected with due diligence (Fig. 2I). Prior to Konta et al. (2021) and the present work, only two unpublished nrDNA sequences and the master record of a whole genome shotgun sequencing project belonging to $E$. cinctus JCM 7946 (BCKC00000000) were available in GenBank. A large number of anamorphic genera such as Endocalyx currently lack molecular data and therefore thorough review of past literature together with careful examination of authentic specimens and cultures is still essential to avoid redescribing old and well documented taxa as new.

In general, isolates of E. melanoxanthus showed a surprisingly low genetic divergence despite originating from three disjunct tropical or subtropical locations such as Japan, Hawaii and Texas. Sequences belonging to "E. metroxyli" from Thailand, synonymized here under E. melanoxanthus, were also nearly identical to the Japanese, Hawaiian and Texan collections. The only exception was the strain Endocalyx sp. MAFF 244025 which showed a considerable genetic variation in its ITS and may represent a distinct population of the fungus growing on the same palm host in the Ogasawara Islands although further conclusions remain pending in the absence of additional molecular data or specimen examination. The Ogasawara Islands is an isolated archipelago in the northwestern Pacific Ocean $1000 \mathrm{~km}$ south of Tokyo with a high level of endemism of its flora and fauna (Kobayashi and Ono 1987; Ito 1998). Endocalyx melanoxanthus is a common colonizer of palm debris with a wide distribution that has been recorded so far from several tropical or subtropical countries including Taiwan (Okada, unpublished) on many different palm hosts (Ellis 1971; Taylor and Hyde 2003; Vitoria et al. 2011; Konta et al. 2021). An online search in the Mycology Collections data Portal [MyCoPortal (http://mycoportal.org/portal/index.php) accessed 26 February 2021] shows a total of 106 records of the fungus in seventeen countries. Its long-distance dispersal is probably favored by its peculiar conidiomata morphology as well as its host association (including tree plantation), but previous knowledge about its intraspecific variability is currently lacking. However, in 1993 G.O. collected some E. melanoxanthus-like fungi on bamboos, as well as E. melanoxanthus on palms (cf., Vitoria et al. 2011), in Brazil, in which the colours of peridial hyphae of the former were slightly different from the latter (Okada, unpublished).

Other species of Endocalyx apparently have more restricted distributions. Endocalyx grossus, elevated here to the species rank, is known only from $T$. fortunei, a cold-hardy palm native to Japan and other Asian countries. We speculate that $E$. grossus evolved later from other tropical or subtropical Endocalyx species (Fig. 1). Similarly, E. indumentum, a species distinct in having conidia densely covered by a hair-like, filamentous ornamentation and dark brown, larger conidiomata compared with other taxa (Okada and Tubaki 1984), is known so far only from the endemic palm tree L. chinensis var. boninensis in the Ogasawara Islands. However, G.O. collected this species in Brazil in 1993 on bamboos and Indonesia in 2011 on Carpentaria acuminata Becc. (Okada, unpublished; E. melanoxanthus was also found coexisting on the same sample of $C$. acuminata), and therefore it is likely that more collections will show a wider distribution and genetic divergence. Similarly, E. cinctus has been collected also from distant locations such as Argentina (Capdet and Romero 2012), Ghana (Hughes 1953a), Japan (Okada and Tubaki 1984), Sri Lanka (Petch 1908, type locality) and Brazil (Okada, unpublished). It is interesting to note that $E$. melanoxanthus was found growing together with $E$. cinctus (e.g., ILLS 121502) and E. indumentum (e.g., ILLS 121501 and an Indonesian collection) on the same palm debris. Endocalyx grossus, on the other hand, only colonizes $T$. fortunei as far as we know although $E$. melanoxanthus rarely occurs on this host (Okada and Tubaki 1984, p. 301). Future morphological, ecological and phylogenetic studies using more specimens, isolates and additional molecular markers will help increase our limited knowledge of their intraspecific variability as well as their species boundaries.

The putative placement of Endocalyx within the family Apiosporaceae (Hyde et al. 1998, 2020; Taylor and Hyde 2003; Senanayake et al. 2015; Wijayawardene et al. 2021) was not supported in our analyses. The four Endocalyx species treated in this paper clustered within the distant family Cainiaceae in Xylariales in agreement with Konta et al. (2021). Okada and Tubaki (1984) previously pointed out that the term 'basauxic' refers to the nature of conidiophores, and conidiogenesis in Endocalyx was not the same as in Arthrinium or Spegazzinia. They even rejected the term 'sympodial proliferation' used by Ellis (1971) to be applied to conidiogenesis in Endocalyx and based on light microscopy and SEM ultrastructural studies they only found basauxic elongation of conidiophores and holoblastic conidiogenesis, but no conidiophore mother-cells. These structures were not found during examination of the Texas specimens. Neither Hughes (1953a) nor Ellis (1971) described conidiophore mother-cells in Endocalyx. They stated that conidiophores are continuations of the core of hyphae at the base of the fructifications which elongate and anastomose to produce thread-like geniculate conidiophores. Other anamorphic genera considered putative members of Apiosporaceae were Spegazzinia Sacc. and Dictyoarthrinium S. Hughes. Recent phylogenetic studies, however, assigned them to 
the family Didymosphaeriaceae in Pleosporales (Dothideomycetes) (Tanaka et al. 2015; Samarakoon et al. 2020a, b) and therefore they are phylogenetically distant from Endocalyx and Arthrinium in Xylariales and Amphisphaeriales, respectively. Anamorphs having basauxic conidiophores are clearly not a uniform group and the absence of conidiophore mother-cells in Endocalyx is phylogenetically significant among them similar to the differences noted by Kirschner et al. (2017) between modes of conidiogenesis in Spegazzinia and Arthrinium. Anamorphic fungi with this mode of conidiophore elongation do not represent a natural group and this feature is shown to have evolved independently within unrelated or even distant ascomycetous lineages.

The family Cainiaceae (Krug 1977) was recently defined in the last outline of the class Sordariomycetes (Hyde et al. 2020) and accepted within Xylariales along with fifteen other families. Konta et al. (2021) keyed out eight genera in Cainiaceae including the anamorphic Endocalyx and refrained from comparing the genus with other members of the family as they have been described solely based on their teleomorphs. However, a morphological connection between some of them and Endocalyx is supported by the presence of germ slits in both their ascospores and conidia. Other features such as the very dark brown ascospores at maturity, globose but also ellipsoidal in shape, unicellular to 1-septate with ornamented walls having reticulations or longitudinal striations (Kang et al. 1999; Senanayake et al. 2015) may also be considered reminiscent of conidia of some Endocalyx species. Seynesia erumpens, for example, has two-celled ascospores with a full-length germ slit in each cell (Hyde 1995). Together with S. nobilis (Welw. \& Curr.) Sacc., the type species of the genus currently lacking molecular data, they are also pantropical in distribution and found as saprobic colonizing petioles and stems of various palm trees and bamboos. Other Arecophila species without available sequence data are also known to colonize rachides or dead trunk and wood of palm species (Hyde 1996). In contrast, Cainia species are mainly saprobic or pathogenic on grasses (Poaceae) (Senanayake et al. 2015), whereas Amphibambusa bambusicola D.Q. Dai \& K.D. Hyde occurs on dead culms of bamboo species (Umali et al. 1999; Liu et al. 2015). Anamorphs are poorly known in the family, but Hyde (1995) reported the production of pycnidial, globose conidiomata in S. erumpens on oatmeal agar which is morphologically dissimilar from Endocalyx in having falcate to lunate, unicellular, hyaline conidia. Müller and Corbaz (1956) also reported that $C$. desmazieri C. Moreau \& E. Müll. [= C. incarcerata (Desm.) E. Müll. \& Arx] produced an anamorph in culture referred to Rhabdospora (Durieu \& Mont.) Sacc. at a time when formally naming different morphs of a pleomorphic fungus was standard practice but unnecessary today under the provisions of the current code (Turland et al. 2018). Nevertheless, they remarked this generic placement was doubtful and successive authors have been unable to re-obtain this anamorph in culture (Krug 1977; Kang et al. 1999; Senanayake et al. 2015). Rhabdospora is a poorly defined, Septoria-like genus in need of revision with most of its accepted species currently placed in Septoria Sacc. (Mycosphaerellaceae, Capnodiales, Dothideomycetes) (Quaedvlieg et al. 2013; Verkley et al. 2013) and therefore phylogenetically unrelated to Cainia and Endocalyx in the Sordariomycetes.

\section{Declarations}

Acknowledgments The University of Tokyo Chichibu Forest (Japan) is thanked for permission to G.O. to collect samples in Chichibu. The Support Unit for Bio-Material Analysis, RIKEN CBS Research Resources Division, is also thanked for technical help with DNA sequencing of JCM strains. NBRC kindly supplied two Endocalyx cultures to G.O. for sequencing. G.D. gratefully acknowledges Michael Mannings, Yandi Gonzales and Kamash Pillai (EMLab P\&K, USA) for technical assistance and provision of laboratory facilities. Tsuyoshi Hosoya (TNS, Japan) and B. Aguirre-Hudson (IMI, UK) are thanked for providing information about Endocalyx specimens deposited in their respective herbaria. Special thanks are also due to M. Piepenbring (Goethe University, Germany) and M. Hernández-Restrepo (CBS, The Netherlands) for serving as pre-submission reviewers of a previous draft of the manuscript.

Author Contributions Conceived and designed the experiments: G.D., G.O. Field work, morphological and cultural studies: G.O., G.D. Molecular work: A.H., A.N.M., T.I. Phylogenetic analyses: G.D., A.N.M. Writing and reviewing the paper: G.D., G.O. Editing the draft: G.D., G.O., A.N.M, A.H., T.I., M.O. All authors read and agreed to the published version of the manuscript.

Funding information Many samples were obtained by G.O. during the Second General Survey on Natural Environment of the Ogasawara (Bonin) Islands (1990-1991) supported by the Tokyo Metropolitan University (Japan), a field trip to Brazil in 1993 as part of a cooperative program to develop a culture collection in Campinas funded by the Japan International Cooperation Agency (JICA, Japan), and a field trip to Indonesia in 2011 as part of a cooperative program to support a LIPI culture collection in Cibinong funded by JICA and Japan Science and Technology Agency (JST, Japan). 
Conflict of interest The authors declare that they have no conflict of interests.

Consent to participate Not applicable.

Consent for publication Not applicable.

Availability of data and materials Sequence data are available in the NCBI GenBank (https://www.ncbi.nlm.nih.gov) under the accession numbers given in Table 1; sequence alignments are available in TreeBase (https://www.treebase.org/); new combination name was registered in MycoBank (https://www.mycobank.org/); specimens and strains are deposited in herbaria TNS or ILLS and culture collections JCM or CBS, respectively, with acronyms explained in the text.

\section{References}

1. Alfaro ME, Zoller S, Lutzoni F (2003) Bayes or bootstrap? A simulation study comparing the performance of Bayesian Markov chain Monte Carlo sampling and bootstrapping in assessing phylogenetic confidence. Mol Biol Evol 20:255-266. https://academic.oup.com/mbe/article/20/2/255/1003275

2. Arx JAvon (1985) Notes on Triadelphia and related genera (Moniliales). Trans Br Mycol Soc 85:564-566. https://www.sciencedirect.com/science/article/pii/S0007153685800644

3. Begerow D, Stoll M, Bauer R (2006) A phylogenetic hypothesis of Ustilaginomycotina based on multiple gene analyses and morphological data. Mycologia 98:906-916. https://www.tandfonline.com/doi/abs/10.1080/15572536.2006.11832620

4. Berkeley MJ, Broome CE (1875) Enumeration of the fungi of Ceylon. Part II, containing the remainder of the Hymenomycetes, with the remaining established tribes of fungi. J Linn Soc Bot 14:29-140. https://www.biodiversitylibrary.org/item/8365\#page/36/mode/1up

5. Berkeley MJ, Broome CE (1877) Supplement to the enumeration of fungi of Ceylon. J Linn Soc Bot 15:82-86. https://www.biodiversitylibrary.org/item/8366\#page/91/mode/1up

6. Capdet M, Romero Al (2012) Ascomicetes sobre palmeras nativas de la Argentina. II: Anamorfos. Bol Soc Argent Bot 47:303310. https://www.scribd.com/doc/173208145/Ascomicetes-sobre-palmeras-nativas-de-la-Argentina

7. Choi YW, Hyde KD, Ho WH (1999) Single spore isolation of fungi. Fungal Divers 3:29-38. https://fungaldiversity.org/fdp/sfdp/FD_3_29-38.pdf

8. Corte AM (1963) Revisione della famiglia Graphiolaceae (Deuteromycetes). Atti Ist Bot Lab Crittog Univ Pavia ser 5 20:253269

9. Crous PW, Groenewald JZ (2013) A phylogenetic re-evaluation of Arthrinium. IMA Fungus 4:133-154. https://imafungus.biomedcentral.com/articles/10.5598/imafungus.2013.04.01.13

10. Drummond AJ, Ho SYW, Phillips MJ, Rambaut A. (2006) Relaxed phylogenetics and dating with confidence. PLoS Biol 4(5): e88. https://doi.org/10.1371/journal.pbio.0040088

11. Drummond AJ, Rambaut A (2009) 18 - Bayesian evolutionary analysis by sampling trees. In: Lemey P, Salemi M, Vandamme AM (eds) The phylogenetic handbook: a practical approach to phylogenetic analysis and hypothesis testing, 2 nd edn. Cambridge University Press, Cambridge, pp 564-591

12. Ellis MB (1971) Dematiaceous Hyphomycetes. Commonwealth Mycological Institute, Kew

13. Gardes M, Bruns TD (1993) ITS primers with enhanced specificity for basidiomycetes: application to the identification of mycorrhizae and rusts. Mol Ecol 2:113-118. https://onlinelibrary.wiley.com/doi/epdf/10.1111/j.1365-294X.1993.tb00005.x

14. Hashimoto A, Masumoto H, Endoh R, Degawa Y, Ohkuma M (2021) Revision of Xylonaceae (Xylonales, Xylonomycetes) to include Sarea and Tromera. Mycoscience 62:47-63. https://www.jstage.jst.go.jp/article/mycosci/62/1/62_MYC514/_article/char/ja/

15. Hawksworth DL (2013) Mycospeak and biobabble. IMA Fungus 4:A1. https://imafungus.biomedcentral.com/articles/10.1007/BF03449519

16. Hillis DM, Bull JJ (1993) An empirical test of bootstrapping as a method for assessing confidence in phylogenetic analysis. Syst Biol 42:182-192. https://academic.oup.com/sysbio/article-abstract/42/2/182/1730933 
17. Hughes SJ (1953a) Fungi from the Gold Coast. II. Mycol Pap 50:1-104

18. Hughes SJ (1953b) Conidiophores, conidia and classification. Can J Bot 31:577-659.

https://cdnsciencepub.com/doi/10.1139/b53-046

19. Hughes SJ (1978) New Zealand fungi 25. Miscellaneous species. New Zeal J Bot 16:311-370.

https://doi.org/10.1080/0028825X.1978.10425143

20. Hyde KD (1995) Fungi from palms. XXI. The genus Seynesia. Sydowia 47:199-212

21. Hyde KD (1996) Fungi from palms. XXIX. Arecophila gen. nov. (Amphisphaeriaceae, Ascomycota), with five new species and two new combinations. Nova Hedwigia 63:81-100

22. Hyde KD, Fröhlich J, Taylor JE (1998) Fungi from palms. XXXVI. Reflections on unitunicate ascomycetes with apiospores. Sydowia 50:21-80

23. Hyde KD, Norphanphoun C, Maharachchikumbura SSN et al. (2020) Refined families of Sordariomycetes. Mycosphere 11:3051059. https://www.mycosphere.org/pdf/MYCOSPHERE_11_1_7.pdf

24. Ito M (1998) Origin and evolution of endemic plants of the Bonin (Ogasawara) Islands. Res Popul Ecol 40:205-212.

25. https://esj-journals.onlinelibrary.wiley.com/doi/abs/10.1007/BF02763405

26. Jaklitsch WM, Fournier J, Rogers JD, Voglmayr H (2014) Phylogenetic and taxonomic revision of Lopadostoma. Persoonia 32:52-82. https://www.ingentaconnect.com/content/nhn/pimj/2014/00000032/00000001/art00004

27. Jaklitsch WM, Gardiennet A, VogImayr H (2016) Resolution of morphology-based taxonomic delusions: Acrocordiella, Basiseptospora, Blogiascospora, Clypeosphaeria, Hymenopleella, Lepteutypa, Pseudapiospora, Requienella, Seiridium and Strickeria. Persoonia 37:82-105. https://www.ingentaconnect.com/content/nhn/pimj/2016/00000037/00000001/art00006

28. Kang JC, Hyde KD, Kong RYC (1999) Studies on Amphisphaeriales: the Cainiaceae. Mycol Res 103:1621-1627. https://www.sciencedirect.com/science/article/pii/S0953756208603354

29. Kapoor JN, Munjal RL (1966) Indian species of Stilbaceae. Indian Phytopathol 19:346-356

30. Katoh K, Misawa K, Kuma K, Miyata T (2002) MAFFT: a novel method for rapid multiple sequence alignment based on fast Fourier transform. Nucleic Acids Res 30:3059-3066. https://academic.oup.com/nar/article/30/14/3059/2904316

31. Katoh K, Standley DM (2013) MAFFT Multiple Sequence Alignment Software version 7: improvements in performance and usability. Mol Biol Evol 30:772-780. https://academic.oup.com/mbe/article/30/4/772/1073398

32. Kendrick WB, Murase G (1994) Can we recognize monophyletic groups among hyphomycetes? In: Hawksworth DL (ed) Ascomycete systematics: problems and perspectives in the nineties. Springer, New York, pp 101-108

33. Kirschner R (2019) Sex does not sell: the argument for using the terms "anamorph" and "teleomorph" for fungi. Mycol Progress 18:305-312. https://link.springer.com/article/10.1007/s11557-018-1421-6

34. Kirschner R, Villarreal RVS, Hofmann TA (2017) A new species of Shrungabeeja (Tetraplosphaeriaceae) and new records of saprobic dematiaceous hyphomycetes on Poaceae from the high mountains of Panama. Sydowia 69:153-160. http://sydowia.at/syd69/T17-Kirschner.htm

35. Kobayashi S, Ono M (1987) A revised list of vascular plants indigenous and introduced to the Bonin (Ogasawara) and the Volcano (Kazan) Islands. Ogasawara Res 13:1-55

36. Konta S, Hyde KD, Eungwanichayapant PD, Karunarathna SC et al. (2021) Multigene phylogeny reveals Haploanthostomella elaeidis gen. et sp. nov. and familial replacement of Endocalyx (Xylariales, Sordariomycetes, Ascomycota). Life 11(486):1-25. https://www.mdpi.com/2075-1729/11/6/486/html

37. Krug JC (1977) The genus Cainia and a new family, Cainiaceae. Sydowia 30:122-133

38. Liu JK, Hyde KD, Jones EBG et al. (2015) Fungal diversity notes 1-110: taxonomic and phylogenetic contributions to fungal species. Fungal Divers 72:1-197. https://link.springer.com/article/10.1007/s13225-015-0324-y

39. Mena J, Mercado A (1984) Nuevas especies de Endocalyx y Stachylidium (Hyphomycetes, Deuteromycotina) de Cuba. Rev Jard Bot Nac Univ Habana 5:53-60

40. Miller MA, Pfeiffer W, Schwartz T (2010) Creating the CIPRES Science Gateway for inference of large phylogenetic trees. In: Proceedings of the Gateway Computing Environments Workshop (GCE), 14 Nov 2010, New Orleans, pp 1-8 
41. Minter DW (1985) A re-appraisal of the relationships between Arthrinium and other hyphomycetes. Proc Indian Acad Sci (Plant Sci) 94:281-308. https://link.springer.com/article/10.1007/BF03053145

42. Morris EF (1963) The synnematous genera of the Fungi Imperfecti. Western Illinois University, Macomb

43. Müller E, Corbaz R (1956) Kulturversuche mit Ascomyceten III. Sydowia 10:181-188

44. Okada G, Tubaki K (1984) A new species and a new variety of Endocalyx (Deuteromycotina) from Japan. Mycologia 76:300313. https://www.tandfonline.com/doi/abs/10.1080/00275514.1984.12023839

45. Okada G, Tubaki K (1987) Conidiomatal structures of the stilbellaceous and allied fungi. Sydowia 39:148-159

46. Osmundson TW, Eyre CA, Hayden KM, Dhillon J, Garbelotto MM (2013) Back to basics: an evaluation of NaOH and alternative rapid DNA extraction protocols for DNA barcoding, genotyping, and disease diagnostics from fungal and oomycete samples. Mol Ecol Resour 13:66-74. https://onlinelibrary.wiley.com/doi/10.1111/1755-0998.12031

47. Patel US, Pandey AK, Rajak RC (2002) Two new hyphomycetes. J Mycol Plant Pathol 32:70-71

48. Petch T (1908) The genus Endocalyx, Berkeley and Broome. Ann Bot (London) 22:389-400. https://academic.oup.com/aob/article-abstract/os-22/3/389/187261

49. Quaedvlieg W, Verkley GJM, Shin HD et al. (2013) Sizing up Septoria. Stud Mycol 75:307-390. https://www.sciencedirect.com/science/article/pii/S0166061614600063

50. Rambaut A, Suchard MA, Xie D, Drummond AJ (2014) Tracer v1.6. tree.bio.ed.ac.uk/software/tracer/

51. Rehner SA, Samuels GJ (1995) Molecular systematics of the Hypocreales: a teleomorph gene phylogeny and the status of their anamorphs. Can J Bot 73(S1):816-823. https://cdnsciencepub.com/doi/10.1139/b95-327

52. Ronquist F, Huelsenbeck JP (2003) MrBayes 3: Bayesian phylogenetic inference under mixed models. Bioinformatics 19:15721574. https://academic.oup.com/bioinformatics/article/19/12/1572/257621

53. Ronquist $F$, Teslenko M, van der Mark $P$ et al. (2012) MrBayes 3.2: efficient Bayesian phylogenetic inference and model choice across a large model space. Syst Biol 61:539-542. https://academic.oup.com/sysbio/article/61/3/539/1674894

54. Samarakoon BC, Phookamsak R, Wanasinghe DN et al. (2020a) Taxonomy and phylogenetic appraisal of Spegazzinia musae sp. nov. and S. deightonii (Didymosphaeriaceae, Pleosporales) on Musaceae from Thailand. MycoKeys 70:19-37. https://mycokeys.pensoft.net/article/52043/

55. Samarakoon BC, Wanasinghe DN, Samarakoon MC et al. (2020b): Multi-gene phylogenetic evidence suggests Dictyoarthrinium belongs in Didymosphaeriaceae (Pleosporales, Dothideomycetes) and Dictyoarthrinium musaesp. nov. on Musa from Thailand. MycoKeys 71:101-118. https://mycokeys.pensoft.net/article/55493/

56. Sato T, Okada G, Nagao H (1991) Microfungi in the Ogasawara (Bonin) Islands. In: Ono M, Kimura M, Miyashita K, Nogami M (eds) Report of the second general survey on natural environment of the Ogasawara (Bonin) Islands. Tokyo Metropolitan University, Tokyo, pp 56-75 (in Japanese)

57. Seifert KA (2016) In defense of the terms holomorph, teleomorph, and anamorph. IMA Fungus 4:55-56

58. Seifert KA, Morgan-Jones G, Gams W, Kendrick B (2011) The genera of hyphomycetes. CBS-KNAW Fungal Biodiversity Center, Utrecht

59. Seifert KA, Okada G (1990) Taxonomic implications of conidiomatal anatomy in synnematous Hyphomycetes. Stud Mycol 32:29-40

60. Seifert KA, Rossman AY (2010) How to describe a new fungal species. IMA Fungus 1:109-116. https://imafungus.biomedcentral.com/articles/10.5598/imafungus.2010.01.02.02

61. Senanayake IC, Maharachchikumbura SSN, Hyde KD et al. (2015) Towards unraveling relationships in Xylariomycetidae (Sordariomycetes). Fungal Divers 73:73-144. https://link.springer.com/article/10.1007/s13225-015-0340-y

62. Stamatakis A (2014) RAxML version 8: a tool for phylogenetic analysis and post-analysis of large phylogenies. Bioinformatics 30:1312-1313. https://academic.oup.com/bioinformatics/article/30/9/1312/238053

63. Tamura K, Stecher G, Peterson D, Filipski A, Kumar S (2013) MEGA6: Molecular Evolutionary Genetics Analysis version 6.0. Mol Biol Evol 30:2725-2729. https://academic.oup.com/mbe/article/30/12/2725/1017851

64. Tanaka K, Hashimoto A, Sato M, Kaminaga R, Ono T, Sato T (2017) Identification and species diversity of microfungi (Ascomycota) in the Bonin Islands. MAFF Microorganism Genetic Resources Manual 39:1-22 (in Japanese).

Page $14 / 26$ 
https://www.gene.affrc.go.jp/pdf/manual/micro-39.pdf

65. Tanaka K, Hirayama K, Yonezawa H et al. (2015) Revision of the Massarineae (Pleosporales, Dothideomycetes). Stud Mycol 82:75-136. https://www.sciencedirect.com/science/article/pii/S0166061615000160

66. Taylor JE, Hyde KD (2003) Microfungi of tropical and temperate palms. Fungal Diversity Press, Hong Kong

67. Turland NJ, Wiersema JH, Barrie FR et al. (eds) (2018) International Code of Nomenclature for algae, fungi, and plants (Shenzhen Code) adopted by the Nineteenth International Botanical Congress Shenzhen, China, July 2017. Regnum Vegetabile 159. Koeltz Botanical Books, Glashütten. https://www.iapt-taxon.org/nomen/main.php

68. Umali TE, Hyde KD, Quimio TH (1999) Arecophila bambusae sp. nov. and A. coronata comb. nov., from dead culms of bamboo. Mycoscience 40:185-188. https://link.springer.com/article/10.1007/BF02464296

69. Verkley GJM, Quaedvlieg W, Shin HD, Crous PW (2013) A new approach to species delimitation in Septoria. Stud Mycol 75:213-305. https://www.sciencedirect.com/science/article/pii/S0166061614600051

70. Vilgalys R, Hester M (1990) Rapid genetic identification and mapping of enzymatically amplified ribosomal DNA from several Cryptococcus species. J Bact 172:4238-4246. https://journals.asm.org/doi/abs/10.1128/jb.172.8.4238-4246.1990

71. Vitoria NS, Cavalcanti MAQ, Luz EDMN, Bezerra JL (2011) Endocalyx melanoxanthus var. melanoxanthus (Ascomycota): new to Brazil and three new hosts. Mycotaxon 117:109-113.

https://www.ingentaconnect.com/contentone/mtax/mt/2011/00000117/00000001/art00012

72. Wang M, Liu F, Crous PW, Cai L (2017) Phylogenetic reassessment of Nigrospora: ubiquitous endophytes, plant and human pathogens. Persoonia 39:118-142. https://www.ingentaconnect.com/content/nhn/pimj/2017/00000039/00000001/art00006

73. White TJ, Bruns TD, Lee SB, Taylor JW (1990) Amplification and direct sequencing of fungal ribosomal RNA genes for phylogenetics. In: Innis MA, Gelfand DH, Sninsky JJ, White TJ (eds) PCR protocols: a guide to methods and applications. Academic Press, San Diego, pp 315-322

74. Wijayawardene NN, Hyde KD, Anand G, Dissanayake LS, Tang LZ, Dai DQ (2021) Towards incorporating asexually reproducing fungi in the natural classification and notes for pleomorphic genera. Mycosphere 12:238-405.

https://mycosphere.org/pdf/MYCOSPHERE_12_1_4.pdf

75. Wijayawardene NN, Hyde KD, Tibpromma S, Wanasinghe DN, Thambugala KM, Tian Q, Wang Y, Fu L (2017) Towards incorporating asexual fungi in a natural classification: checklist and notes 2012-2016. Mycosphere 8:1457-1555. https://mycosphere.org/pdf/MYCOSPHERE_8_9_10.pdf

76. Wijayawardene NN, Hyde KD, Lumbsch T, Liu JK, Maharachchikumbura SSN, Ekanayaka AH, Tian Q, Phookamsak R (2018) Outline of Ascomycota: 2017. Fungal Divers 88:167-263. https://link.springer.com/article/10.1007/s13225-018-0394-8

\section{Tables}

Table 1. Endocalyx species, strains and specimens used in this study including palm host, country and sequence information whenever relevant. GenBank accession numbers in bold correspond to sequences generated during this study. 


\begin{tabular}{|c|c|c|c|c|c|}
\hline \multirow[t]{2}{*}{ Species $^{a}$} & \multirow[t]{2}{*}{ st / Country } & \multirow{2}{*}{$\begin{array}{l}\text { Strain and } \\
\text { status }^{b} \\
\text { (including } \\
\text { original TKBC } \\
\text { no.) }\end{array}$} & \multirow{2}{*}{$\begin{array}{l}\text { Voucher } \\
\text { specimen no. } \\
\text { and status }\end{array}$} & \multicolumn{2}{|c|}{ GenBank accession no. } \\
\hline & & & & ITS & LSU \\
\hline Endocalyx cinctus & Phoenix canariensis / Japan & $\begin{array}{l}\text { NBRC/IFO } 31306 \\
\text { (TKBC 1290) }\end{array}$ & $\begin{array}{l}\text { TNS-F-18242, TNS-F- } \\
\text { 18265, IMI } 287889\end{array}$ & MZ313191 & MZ313152 \\
\hline E. cinctus & $\begin{array}{l}\text { Livistona chinensis var. } \\
\text { boninensis / Japan }\end{array}$ & JCM $7946^{\mathrm{C}}$ & $\begin{array}{l}\text { TNS-F-91424 (G. } \\
\text { Okada Ogasawara- } \\
\text { 191), TNS-F-91425 } \\
\text { (ex-JCM 7946) }\end{array}$ & LC228648 & LC228704 \\
\hline E. cinctus & $\begin{array}{l}\text { Livistona chinensis var. } \\
\text { boninensis / Japan }\end{array}$ & - & $\begin{array}{l}\text { ILLS } 121502 \text { (G. } \\
\text { Okada Ogasawara- } \\
\text { 192) }\end{array}$ & - & - \\
\hline E. grossus & $\begin{array}{l}\text { Trachycarpus fortunei / } \\
\text { Japan }\end{array}$ & $\begin{array}{l}\text { JCM } 5164= \\
\text { NBRC/IFO 31308 } \\
\text { (ex-holotype) = } \\
\text { CBS 105.86) }(= \\
\text { TKBC 1286) }\end{array}$ & $\begin{array}{l}\text { TNS-F-18281 } \\
\text { (holotype), CBS H- } \\
12419 \text { (isotype), IMI } \\
287881 \text { (isotype) }\end{array}$ & MZ313160 & MZ313138 \\
\hline E. grossus & T. fortunei / Japan & $\begin{array}{l}\mathrm{JCM} \\
5165=\mathrm{NBRC} / \mathrm{IFO} \\
31309(=\mathrm{TKBC} \\
1287)\end{array}$ & $\begin{array}{l}\text { TNS-F-18252, CBS H- } \\
3951\end{array}$ & MZ313159 & MZ313158 \\
\hline E. grossus & T. fortunei / Japan & $\begin{array}{l}\text { JCM } \\
5166=\text { NBRC/IFO } \\
31310(=\text { TKBC } \\
1292)\end{array}$ & $\begin{array}{l}\text { TNS-F-18248, CBS H- } \\
\text { 3952, IMI } 287883\end{array}$ & MZ313179 & MZ313171 \\
\hline E. grossus & T. fortunei / Japan & $\begin{array}{l}\mathrm{JCM} \\
5167=\mathrm{NBRC} / \mathrm{IFO} \\
31311(=\mathrm{TKBC} \\
1293)\end{array}$ & $\begin{array}{l}\text { TNS-F-18246, CBS H- } \\
3953\end{array}$ & MZ313169 & MZ313174 \\
\hline E. grossus & T. fortunei / Japan & $\begin{array}{l}\text { JCM } 5168= \\
\text { NBRC/IFO } 31312 \\
=\text { CBS 106.86 (= } \\
\text { TKBC 1294) }\end{array}$ & TNS-F-18237 & MZ313165 & MZ313164 \\
\hline E. grossus & T. fortunei / Japan & $\begin{array}{l}\text { JCM } 5169= \\
\text { NBRC/IFO 31313 } \\
(=\text { TKBC 1296) }\end{array}$ & $\begin{array}{l}\text { TNS-F-18245, CBS H- } \\
3954\end{array}$ & MZ313172 & MZ313178 \\
\hline E. grossus & T. fortunei / Japan & $\begin{array}{l}\mathrm{JCM} \\
5170=\mathrm{NBRC} / \mathrm{IFO} \\
31314(=\mathrm{TKBC} \\
1297)\end{array}$ & $\begin{array}{l}\text { TNS-F-18244, CBS H- } \\
3955\end{array}$ & MZ313166 & MZ313170 \\
\hline E. grossus & T. fortunei / Japan & $\mathrm{JCM} 32411^{\mathrm{C}}$ & $\begin{array}{l}\text { TNS-F-91426 (G. } \\
\text { Okada 1763) }\end{array}$ & MZ313163 & MZ313168 \\
\hline E. grossus & T. fortunei / Japan & - & $\begin{array}{l}\text { ILLS } 121505 \text { (G. } \\
\text { Okada 1764) }\end{array}$ & - & - \\
\hline E. grossus & T. fortunei / Japan & JCM $32997^{c}$ & $\begin{array}{l}\text { TNS-F-91427 (G. } \\
\text { Okada 1766), TNS-F- } \\
\text { 91428 (ex-JCM } \\
\text { 32997) }\end{array}$ & MZ313136 & MZ313167 \\
\hline E. grossus & T. fortunei / Japan & - & $\begin{array}{l}\text { ILLS } 121504 \text { (G. } \\
\text { Okada 1767) }\end{array}$ & - & - \\
\hline E. grossus & T. fortunei / Japan & JCM 32998c & $\begin{array}{l}\text { TNS-F-91429 (G. } \\
\text { Okada 1769), TNS-F- } \\
\text { 91430 (ex-JCM } \\
\text { 32998) }\end{array}$ & MZ313176 & MZ313177 \\
\hline
\end{tabular}




\begin{tabular}{|c|c|c|c|c|c|}
\hline E. grossus & T. fortunei / Japan & - & $\begin{array}{l}\text { ILLS } 121506 \text { (G. } \\
\text { Okada 1770) }\end{array}$ & - & - \\
\hline E. grossus & T. fortunei / Japan & JCM $33339^{c}$ & $\begin{array}{l}\text { TNS-F-91431 (G. } \\
\text { Okada 1772) }\end{array}$ & MZ313175 & MZ313173 \\
\hline E. indumentum & Phoenix canariensis / Japan & - & $\begin{array}{l}\text { ILLS } 121501=\mathrm{G} \text {. } \\
\text { Okada Ogasawara- } \\
80\end{array}$ & - & - \\
\hline E. indumentum & $\begin{array}{l}\text { L. chinensis var. boninensis / } \\
\text { Japan }\end{array}$ & $\begin{array}{l}\text { JCM } 5171= \\
\text { NBRC/IFO 31307 } \\
\text { (ex-holotype), } \\
\text { CBS 104.86 (= } \\
\text { TKBC 1285) }\end{array}$ & $\begin{array}{l}\text { TNS-F- } \\
18280 \text { (holotype), IMI } \\
287888 \text { (isotype) }\end{array}$ & MZ313153 & MZ313161 \\
\hline E. indumentum & $\begin{array}{l}\text { L. chinensis var. } \\
\text { boninensis / Japan }\end{array}$ & $\mathrm{JCM} 8042^{\mathrm{C}}$ & $\begin{array}{l}\text { TNS-F-91432 (G. } \\
\text { Okada Ogasawara- } \\
\text { 200), TNS-F-91433 } \\
\text { (ex-JCM 8042) }\end{array}$ & MZ313162 & MZ313157 \\
\hline E. melanoxanthus & Sabal minor/ Texas, USA & CBS 147393 & ILLS 121433 & MW718204 & MW718204 \\
\hline E. melanoxanthus & S. minor / Texas, USA & CBS 147394 & ILLS 121434 & MW718203 & MW718203 \\
\hline E. melanoxanthus & $\begin{array}{l}\text { L. chinensis var. subglobosa / } \\
\text { Japan }\end{array}$ & $\begin{array}{l}\text { JCM } 5156= \\
\text { NBRC/IFO 31298 } \\
(=\text { TKBC 1281) }\end{array}$ & $\begin{array}{l}\text { TNS-F-18239, CBS H- } \\
3945, \text { IMI } 287873\end{array}$ & MZ313137 & MZ313135 \\
\hline E. melanoxanthus & $\begin{array}{l}\text { L. chinensis var. subglobosa / } \\
\text { Japan }\end{array}$ & $\begin{array}{l}\text { NBRC/IFO } 31299 \\
=\text { CBS 107.86 (= } \\
\text { TKBC 1282) }\end{array}$ & TNS-F-18253 & MZ313147 & MZ313148 \\
\hline E. melanoxanthus & $\begin{array}{l}\text { Washingtonia robusta / } \\
\text { Japan }\end{array}$ & $\begin{array}{l}\text { JCM } \\
5158=\text { NBRC/IFO } \\
31300(=\mathrm{TKBC} \\
1283)\end{array}$ & $\begin{array}{l}\text { TNS-F-18262, CBS H- } \\
\text { 3946, IMI } 287875\end{array}$ & MZ313139 & MZ313143 \\
\hline E. melanoxanthus & $\begin{array}{l}\text { L. chinensis var. } \\
\text { boninensis / Japan }\end{array}$ & $\begin{array}{l}\text { JCM } \\
5159=\text { NBRC/IFO } \\
31301(=\text { TKBC } \\
1284)\end{array}$ & $\begin{array}{l}\text { TNS-F-18240, CBS H- } \\
3947\end{array}$ & MZ313146 & MZ313145 \\
\hline E. melanoxanthus & $\begin{array}{l}\text { L. chinensis var. subglobosa / } \\
\text { Japan }\end{array}$ & $\begin{array}{l}\text { JCM } 5160= \\
\text { NBRC/IFO 31302 } \\
(=\text { TKBC 1288) }\end{array}$ & $\begin{array}{l}\text { TNS-F-18268, CBS H- } \\
3948, \text { IMI } 287877\end{array}$ & MZ313144 & MZ313142 \\
\hline E. melanoxanthus & P. roebelenii / Japan & $\begin{array}{l}\text { JCM } 5161= \\
\text { NBRC/IFO 31303 } \\
(=\text { TKBC 1289) }\end{array}$ & $\begin{array}{l}\text { TNS-F-18247, CBS H- } \\
3949, \text { IMI } 287878\end{array}$ & MZ313150 & MZ313151 \\
\hline E. melanoxanthus & $\begin{array}{l}\text { L. chinensis var. subglobosa / } \\
\text { Japan }\end{array}$ & $\begin{array}{l}\text { JCM } 5163= \\
\text { NBRC/IFO 31305 } \\
(=\text { TKBC 1295) }\end{array}$ & $\begin{array}{l}\text { TNS-F-18251, CBS H- } \\
3950\end{array}$ & MZ313155 & MZ313141 \\
\hline E. melanoxanthus & $\begin{array}{l}\text { L. chinensis var. boninensis / } \\
\text { Japan }\end{array}$ & $\mathrm{JCM} 7948^{\mathrm{C}}$ & $\begin{array}{l}\text { TNS-F-91434 (G. } \\
\text { Okada Ogasawara- } \\
61)\end{array}$ & MZ313140 & MZ313149 \\
\hline E. melanoxanthus & Cocos nucifera / Hawaii, USA & JCM $13432^{c}$ & ILLS 121495 & MZ313156 & MZ313154 \\
\hline E. melanoxanthus & Metroxylon sagu / Thailand & MFLU 15-1454 & MFLUCC 15-0723A & MT929162 & MT929313 \\
\hline E. melanoxanthus & Metroxylon sagu / Thailand & MFLU 15-1454 & MFLUCC 15-0723B & MT929163 & MT929314 \\
\hline E. melanoxanthus & Metroxylon sagu / Thailand & MFLU 15-1454 & MFLUCC 15-0723C & - & MT929315 \\
\hline Endocalyx sp. & $\begin{array}{l}\text { L. chinensis var. boninensis / } \\
\text { Japan }\end{array}$ & MAFF 244025 & HHUF 30261 & $-d$ & - \\
\hline
\end{tabular}

a Species names of Endocalyx including E. grossus and E. melanoxanthus (= E. metroxyli) proposed in this paper. 
${ }^{b}$ Abbreviations: CBS, CBS-KNAW Culture Collection, Westerdijk Fungal Biodiversity Institute, Utrecht, The Netherlands. IFO, Institute for Fermentation, Osaka, Japan (collection transferred to NBRC). HHUF, Herbarium of Plant Pathology Laboratory, Faculty of Agriculture and Life Science, Hirosaki University, Hirosaki, Japan. ILLS, Illinois Natural History Survey Fungarium, Champaign, USA. IMI, Herbarium of CABI Bioscience UK Center, Surrey, UK. JCM, Japan Collection of Microorganisms, RIKEN BioResource Research Center, Tsukuba, Japan. MAFF, NARO Genebank, Microorganism Section, Ministry of Agriculture, Forestry and Fisheries, Tsukuba, Japan. MFLU/MFLUCC, Herbarium/Culture Collection, Mae Fah Luang University, Chiang Rai, Thailand. NBRC, NITE Biological Resource Center, Kisarazu, Japan. TKBC, Culture Collection of Mycology Laboratory, Institute of Biological Sciences, University of Tsukuba, Tsukuba, Japan (collection closed). TNS, National Museum of Nature and Science, Tsukuba, Japan.

${ }^{c}$ For further strain details see the JCM on-line catalogue of strains (https://jcm.brc.riken.jp/en/catalogue_e).

${ }^{d}$ Available from NARO Genebank database (https://www.gene.affrc.go.jp/databases_en.php).

Table 2. Fungal taxa, strains and sequences included in this study. 


\begin{tabular}{|c|c|c|c|}
\hline \multirow[t]{2}{*}{ Taxon } & \multirow[t]{2}{*}{ Strain } & \multicolumn{2}{|c|}{ GenBank accession no. } \\
\hline & & ITS & LSU \\
\hline Achaetomium macrosporum & CBS 532.94 & KX976574 & KX976699 \\
\hline Acrocordiella occulta & CBS 140501 & KT949894 & KT949894 \\
\hline Acrocordiella occulta & CBS 140500 & KT949893 & KT949893 \\
\hline Alishanica miscanthi & FU 31025 & MK503821 & MK503827 \\
\hline Amphibambusa bambusicola & MFLUCC 11-0617 & KP744433 & KP744474 \\
\hline Amphisphaeria sorbi & MFLUCC 13-0721 & KR092797 & KP744475 \\
\hline Amphisphaeria thailandica & MFLU 18-0794 & MH971225 & MH971235 \\
\hline Amphisphaeria umbrina & CBS 172.96 & - & FJ176863 \\
\hline Anthostomelloides brabeji & CBS 110128 & EU552098 & EU552098 \\
\hline Arthrinium hysterinum & ICMP 6889 & MK014874 & MK014841 \\
\hline Arecophila bambusae & HKUCC 4794 & - & AF452038 \\
\hline Arecophila muroiana & GZUCC 0122 & MT742127 & MT742134 \\
\hline Arthrinium arundinis & CBS 450.92 & AB220259 & KF144932 \\
\hline Arthrinium arundinis & CBS 145128 & MK014868 & MK014835 \\
\hline Arthrinium hysterinum & CBS 145135 & MK014877 & MK014844 \\
\hline Arthrinium marii & CBS 497.90 & AB220252 & KF144947 \\
\hline Arthrinium phaeospermum & CBS 114318 & KF144907 & KF144954 \\
\hline Arthrinium sacchari & CBS 301.49 & KF144917 & KF144963 \\
\hline Atrotorquata lineata & HKUCC 3263 & AF009807 & - \\
\hline Barrmaelia macrospora & BM & KC774566 & KC774566 \\
\hline Barrmaelia moravica & $\mathrm{Cr} 1$ & MF488987 & MF488987 \\
\hline Barrmaelia oxyacanthae & CBS 142769 & MF488988 & MF488988 \\
\hline Barrmaelia rappazii & CBS 142770 & MF488989 & MF488989 \\
\hline Barrmaelia rhamnicola & CBS 142771 & MF488990 & MF488990 \\
\hline Cainia anthoxanthi & MFLUCC 15-0539 & KR092787 & KR092777 \\
\hline Cainia desmazieri & WU 33597 & KT949896 & KT949896 \\
\hline Cainia globosa & MFLUCC 13-0663 & KX822127 & KX822123 \\
\hline Cainia graminis & CBS 136.62 & MH858123 & AF431949 \\
\hline Cainia graminis & MFLUCC 15-0540 & KR092793 & KR092781 \\
\hline Chaetomium elatum & CBS 374.66 & KC109758 & MH870466 \\
\hline Collodiscula japonica & CBS 124266 & JF440974 & JF440974 \\
\hline Daldinia palmensis & CBS 113039 & MH862912 & MH874486 \\
\hline Daldinia placentiformis & MUCL 47603 & AM749921 & KY610440 \\
\hline Daldinia pyrenaica & MUCL 53969 & KY610413 & KY610413 \\
\hline
\end{tabular}

Page 19/26 


\begin{tabular}{|c|c|c|c|}
\hline Daldinia raimundi & CBS 113038 & JX658517 & MH874485 \\
\hline Daldinia theissenii & CBS 113044 & KY610388 & KY610441 \\
\hline Entonaema liquescens & ATCC 46302 & KY610389 & KY610443 \\
\hline Entosordaria perfidiosa & BW3 & MF488992 & MF488992 \\
\hline Entosordaria perfidiosa & CBS 142773 & MF488993 & MF488993 \\
\hline Entosordaria quercina & CBS 142774 & MF488994 & MF488994 \\
\hline Hypocopra rostrata & NRRL 66178 & KM067909 & KM067909 \\
\hline Hypoxylon fragiforme & DMS 9335105 & MT644893 & MT644893 \\
\hline Hypoxylon haematostroma & MUCL 47600 & AM749924 & KY610447 \\
\hline Hypoxylon investiens & CBS 118183 & KC968925 & KY610450 \\
\hline Hypomontagnella monticulosa & MUCL 54604 & KY610404 & KY610487 \\
\hline Hypoxylon perforatum & CBS 115281 & KY610391 & KY610455 \\
\hline Hypoxylon pulicicidum & CBS 122622 & JX183076 & KY610492 \\
\hline Lepteutypa sambuci & CBS 131707 & KT949904 & KT949904 \\
\hline Lepteutypa uniseptata & CBS 114967 & MH553979 & MH554197 \\
\hline Lopadostoma pouzarii & CBS 103.96 & KC774601 & KC774601 \\
\hline Lopadostoma pouzarii & MUCL 47149 & KC774602 & KC774602 \\
\hline Monochaetia monochaeta & CBS 199.82 & MH554018 & MH554238 \\
\hline Neopestalotiopsis protearum & CBS 114178 & JN712498 & JN712564 \\
\hline Nigrospora camelliae-sinensis & CGMCC3.18125 & KX985986 & KX986103 \\
\hline Nigrospora chinensis & CGMCC3.18127 & KX986023 & KX986107 \\
\hline Nigrospora musae & CBS 319.34 & KX986076 & KX986110 \\
\hline Nigrospora oryzae & CBS 231.32 & MH855300 & MH866754 \\
\hline Nigrospora sphaerica & LC 7298 & KX985937 & KX986097 \\
\hline Requienella fraxini & CBS 140475 & KT949910 & KT949910 \\
\hline Requienella seminuda & CBS 140502 & KT949912 & KT949912 \\
\hline Seimatosporium pistaciae & CBS 138865 & KP004463 & KP004491 \\
\hline Seimatosporium rosae & CBS 139823 & KT198726 & KT198727 \\
\hline Seiridium marginatum & CBS 140403 & KT949914 & MH878679 \\
\hline Seynesia erumpens & SMH 1291 & - & AF279410 \\
\hline Sordaria fimicola & CBS 723.96 & MH862606 & MH874231 \\
\hline Sporocadus incanus & CBS 123003 & MH553991 & MH554210 \\
\hline Sporocadus lichenicola & NBRC 32625 & MH883643 & MH883646 \\
\hline Xylaria frustulosa & ANM 1300 & JN673055 & JN673055 \\
\hline Xylaria grammica & IHI A82 & MK408621 & MK408621 \\
\hline Xylaria hypoxylon & OSC 100004 & DQ491487 & AY544648 \\
\hline Xylaria longipes & DSM 107183 & MK408619 & MK408619 \\
\hline
\end{tabular}

Page 20/26 


\begin{tabular}{|llll|}
\hline Xylaria multiplex & DSM 110363 & MN833802 & MN833802 \\
\hline Xylaria polymorpha & MUCL 49884 & KY610408 & KT281899 \\
\hline
\end{tabular}

Abbreviations: ANM, Andrew N. Miller. ATCC, American Type Culture Collection, Manassas, USA. CBS, CBS-KNAW Culture Collection, Westerdijk Fungal Biodiversity Institute, Utrecht, The Netherlands. DSM, German Collection of Microorganisms and Cell Cultures, Braunschweig, Germany. GZUCC, Guizhou University Culture Center, Guizhou, P. R. China. HKUCC, The University of Hong Kong Culture Collection, Hong Kong, P.R. China. ICMP, International Collection of Micro-organisms from Plants, Manaaki Whenua Landcare Research, Auckland, New Zealand. IHI, International Institute Zittau, Technische Universität, Dresden, Germany. JCM, Japan Collection of Microorganisms, RIKEN BioResource Research Center, Tsukuba, Japan. MAFF, NARO Genebank, Microorganism Section, Ministry of Agriculture, Forestry and Fisheries, Tsukuba, Japan. LC, Lei Cai. MFLU/MFLUCC, Mae Fah Luang University Herbarium / Culture Collection, Chiang Rai, Thailand. MUCL, Agro-food \& Environmental Fungal Collection, Université Catholique de Louvain, Louvain-la-Neuve, Belgium. NBRC, NITE Biological Resource Center, Kisarazu, Japan. NRRL, Agricultural Research Service Culture Collection, U.S. Department of Agriculture, Peoria, USA. SMH, Sabine M. Huhndorf. WU, Herbarium of the Institute of Botany, University of Vienna, Vienna, Austria.

\section{Figures}




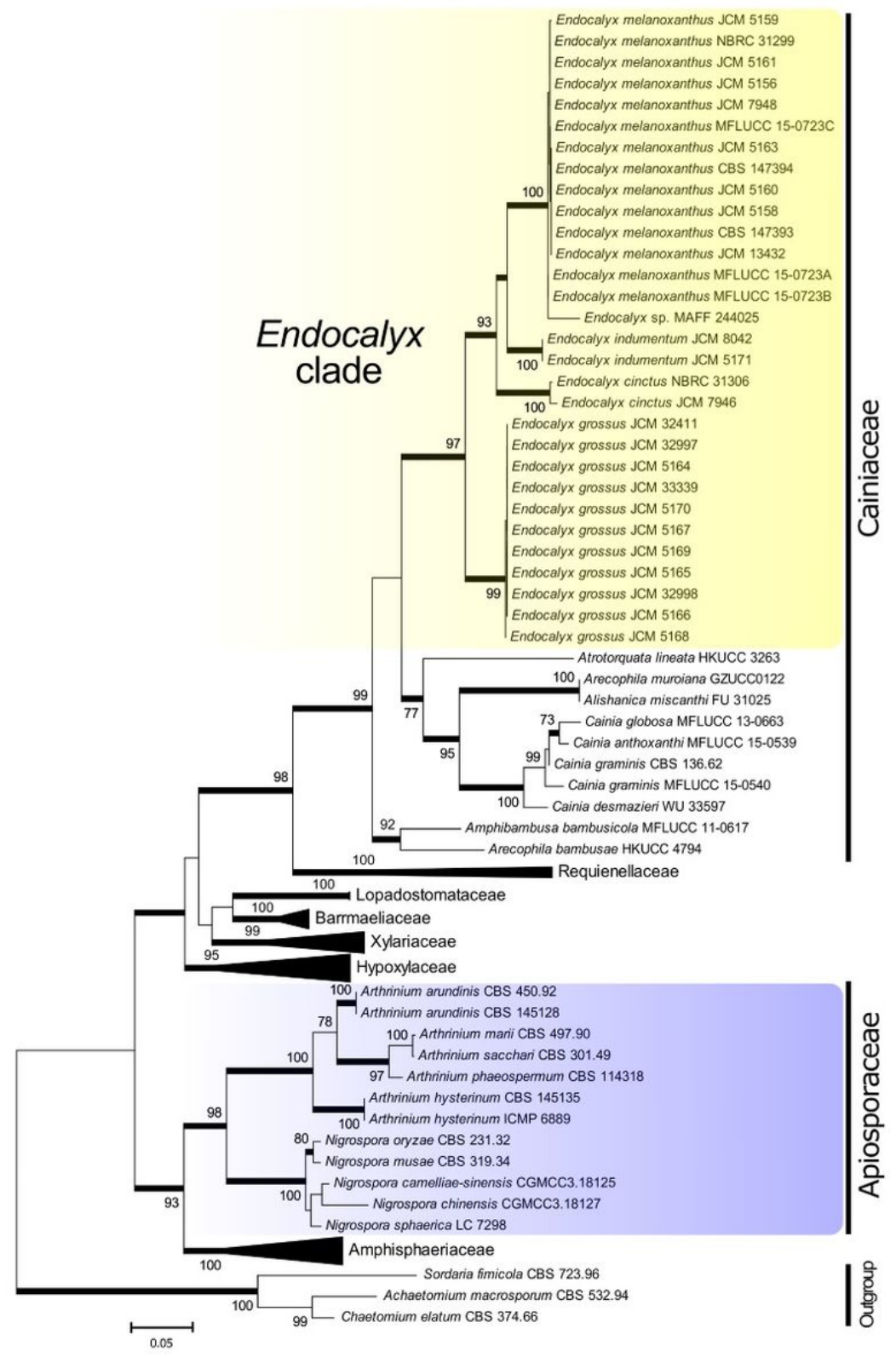

Figure 1

Maximum-likelihood (ML) phylogenetic tree inferred from concatenated ITS-LSU nrDNA sequences belonging to the orders Xylariales and Amphisphaeriales showing the placement of treated Endocalyx species within Cainiaceae. The Endocalyx clade is highlighted in a yellow colour box and the family Apiosporaceae in a blue colour box. Bootstrap support values $\geq 70 \%$ are shown at the nodes and Bayesian posterior probabilities $\geq 0.95$ are indicated by thickened branches. 

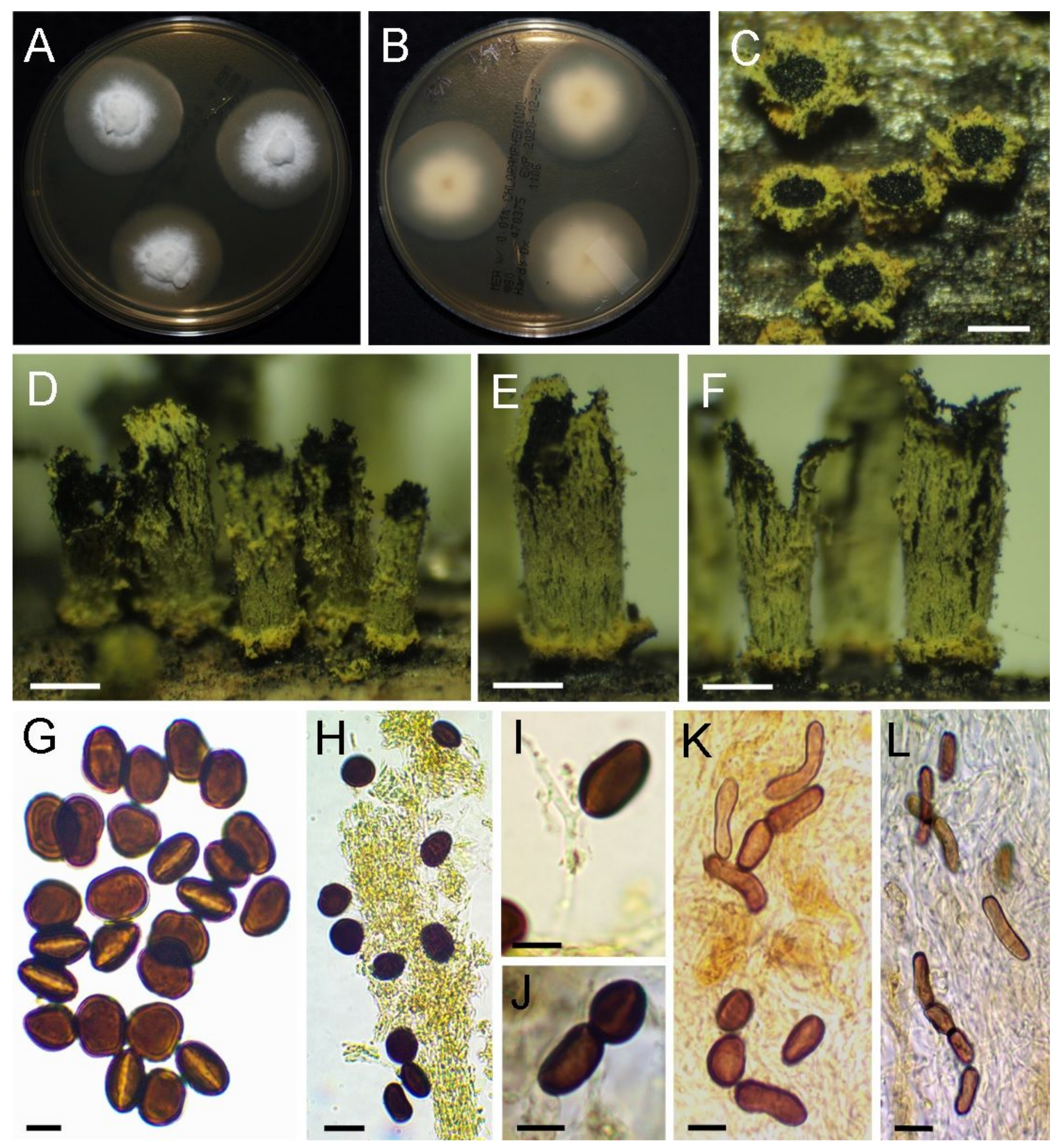

Figure 2

Endocalyx melanoxanthus ILLS 121433 (C-I) \& CBS 147393 (A, B, J-L). A, B. Colonies on MEA after 10 days at $25^{\circ} \mathrm{C}$ (A. Surface view; B. Reverse). C. Upper view of short conidiomata on the natural substrate. D-F. Lateral view of conidiomata after incubation, FSCl. G. Conidia. H. Conidia mixed with yellow peridial hyphae. I. Conidiophore with attached conidium. J-L. Chlamydospores on MEA. Scale bars: $\mathrm{C}-\mathrm{F}=500 \mu \mathrm{m} ; \mathrm{G}, \mathrm{I}-\mathrm{L}=10 \mu \mathrm{m} ; \mathrm{H}=20 \mu \mathrm{m}$. 

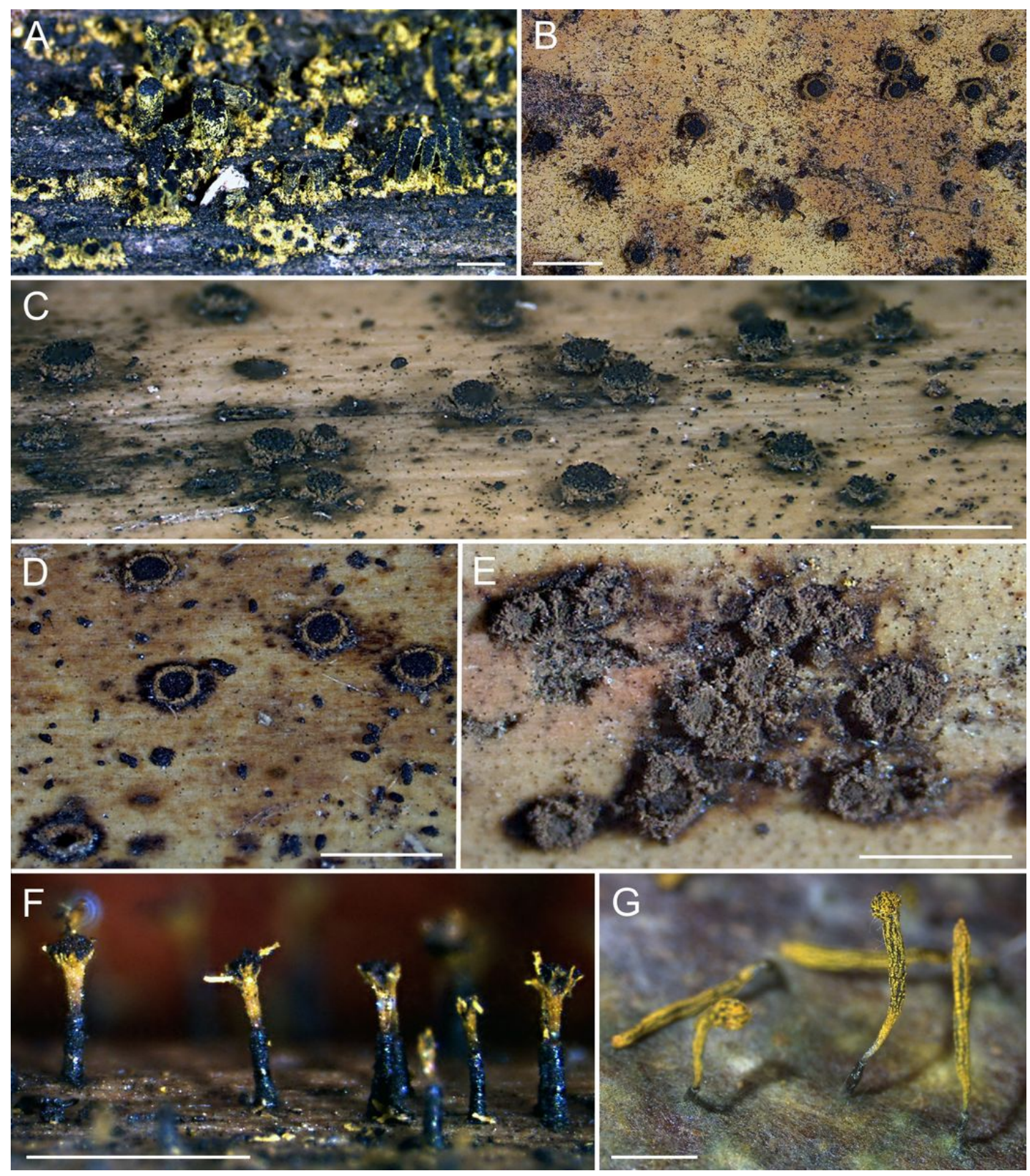

\section{Figure 3}

Conidiomata of Endocalyx species on the hosts and in culture. A. E. melanoxanthus ILLS 121495, FSCI. B-D. E. grossus (B. TNS-F91427; C. TNS-F-91431; D. TNS-F-91429), FSCI. E. E. indumentum TNS-F-91432, FSCI. F, G. E. cinctus (F. TNS-F-91424, FSCl; G. JCM 7946 on autoclaved petiole of Livistona chinensis var. subglobosa in a moist chamber after three months). Scale bars: $1 \mathrm{~mm}$. 


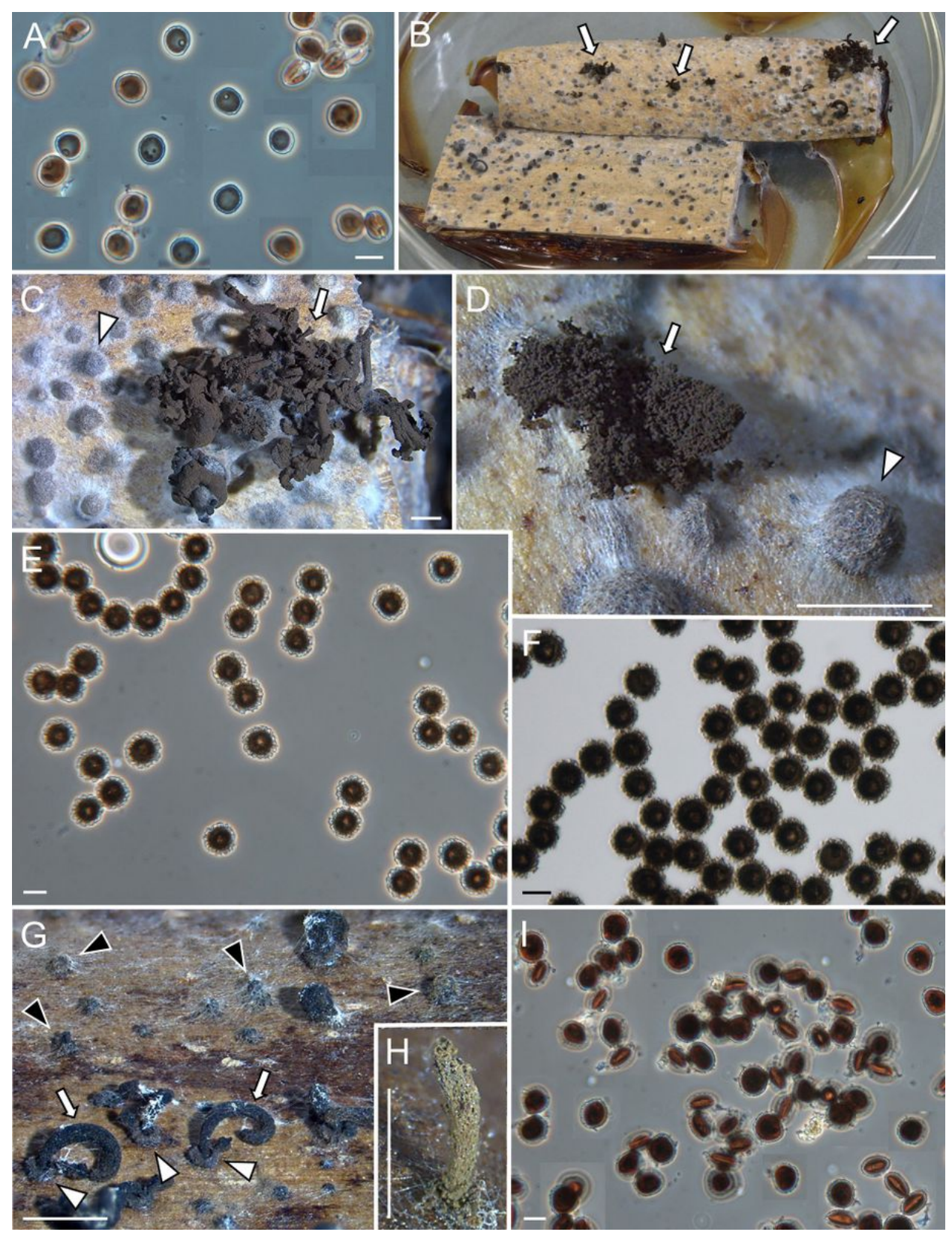

\section{Figure 4}

Endocalyx isolates on autoclaved petioles of the palm hosts. A. Conidia of E. cinctus JCM 7946 on Livistona chinensis var. subglobosa (TNS-F-91425), Cl. B-F. E. indumentum JCM 8042 on L. chinensis var. subglobosa (TNS-F-91433). [B. Pieces of petioles with conidial mass (arrows). C, D. Dark brownish conidial mass (arrows) produced from subspherical conidiomata (arrowheads), FSCI]. E (PC), F (DIC). Conidia with hair-like projections]. G-I. E. grossus JCM 32997 (H. TNS-F-91428) \& JCM 32998 (G, I. TNS-F-91430) on Trachycarpus fortunei [G. Conidial columns (arrows) produced from an annulus-like structure (white arrowheads) associated with subspherical conidiomata (black arrowheads), $\mathrm{FSCl}$. H. A conidial column covered with brown peridial hyphae developing from an annulus-like structure, FSCl. I. Conidia, Cl]. Scale bars: A, E, F, I = $10 \mu \mathrm{m} ; \mathrm{B}=1 \mathrm{~cm} ; \mathrm{C}, \mathrm{D}, \mathrm{G}=1 \mathrm{~mm} ; \mathrm{H}=$ $0.5 \mathrm{~mm}$. 


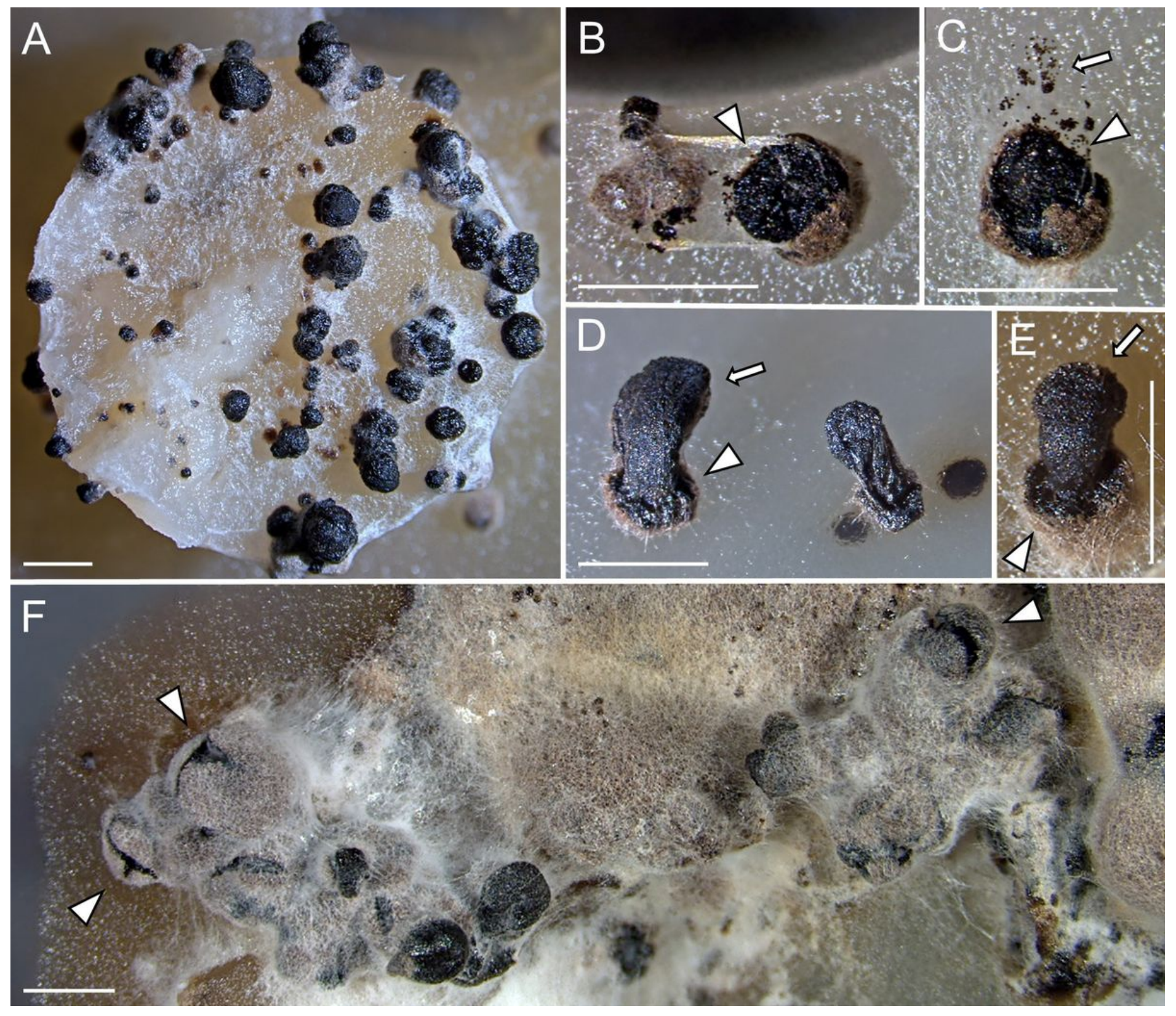

\section{Figure 5}

Subspherical conidiomata of Endocalyx grossus JCM 5166 (A-E) and E. indumentum JCM 8042 (F) on PDA after prolonged incubation at room temperature. A. Blackish mature conidiomata of different sizes on a PDA disk. B, C. Dark brown mass of conidia (arrowheads) filled in subspherical conidiomata and conidia smeared on the medium (arrow). D, E. Conidial columns (arrows) produced from lower part of broken conidiomata (arrowheads). F. Broken conidiomata (arrowheads) in which small immature conidia without filamentous ornamentation were produced inside. Scale bars: $1 \mathrm{~mm}$. 